\title{
Review Article \\ Comprehensive Review of Adipose Stem Cells and Their Implication in Distraction Osteogenesis and Bone Regeneration
}

\author{
Mina W. Morcos, ${ }^{1,2}$ Hadil Al-Jallad, ${ }^{1,3}$ and Reggie Hamdy ${ }^{1,4}$ \\ ${ }^{1}$ Division of Paediatric Orthopaedic Surgery, Shriners Hospital for Children, Montreal Children Hospital, \\ McGill University, 1529 Cedar Avenue, Montreal, QC, Canada H3G 1A6 \\ ${ }^{2}$ Department of Experimental Surgery, McGill University, 1650 Cedar Avenue, Montreal, QC, Canada H3G $1 A 4$ \\ ${ }^{3}$ Orthopaedics Department, Shriners Hospital for Children, 1529 Cedar Avenue, Montreal, QC, Canada H3G $1 A 6$ \\ ${ }^{4}$ McGill University Health Centre, Shriners Hospital for Children, Montreal Children Hospital, 1529 Cedar Avenue, \\ Montreal, QC, Canada H3G $1 A 6$
}

Correspondence should be addressed to Mina W. Morcos; mina.wahbamorcos@mail.mcgill.ca

Received 13 March 2015; Accepted 2 August 2015

Academic Editor: Aijun Wang

Copyright ( 2015 Mina W. Morcos et al. This is an open access article distributed under the Creative Commons Attribution License, which permits unrestricted use, distribution, and reproduction in any medium, provided the original work is properly cited.

\begin{abstract}
Bone is one of the most dynamic tissues in the human body that can heal following injury without leaving a scar. However, in instances of extensive bone loss, this intrinsic capacity of bone to heal may not be sufficient and external intervention becomes necessary. Several techniques are available to address this problem, including autogenous bone grafts and allografts. However, all these techniques have their own limitations. An alternative method is the technique of distraction osteogenesis, where gradual and controlled distraction of two bony segments after osteotomy leads to induction of new bone formation. Although distraction osteogenesis usually gives satisfactory results, its major limitation is the prolonged duration of time required before the external fixator is removed, which may lead to numerous complications. Numerous methods to accelerate bone formation in the context of distraction osteogenesis have been reported. A viable alternative to autogenous bone grafts for a source of osteogenic cells is mesenchymal stem cells from bone marrow. However, there are certain problems with bone marrow aspirate. Hence, scientists have investigated other sources for mesenchymal stem cells, specifically adipose tissue, which has been shown to be an excellent source of mesenchymal stem cells. In this paper, the potential use of adipose stem cells to stimulate bone formation is discussed.
\end{abstract}

\section{Introduction}

Orthopaedic surgeons are always confronted with cases of extensive bone loss-known as critical size defects (CSDs) where outside intervention is necessary for healing to occur. These large defects may be secondary to trauma, postresection of tumors, or postdebridement of infections. The goal in such cases is to align the bone segments together, facilitate union, obtain equal limb length, and restore the function of the traumatized site [1-4]. Various surgical techniques have been used to address these CSDs, including the gold standard autogenous bone grafts, allografts, various bone grafts substitutes, and vascularized and nonvascularized bone grafts $[1,3,5-9]$. However, all these techniques do have multiple limitations [7, 8]. In 1905, an Italian orthopaedic surgeon called Codivilla performed the first lengthening procedure, where he applied skeletal traction through a calcaneal pin followed with an osteotomy of the femur. This proved that limb lengthening could be achieved without jeopardizing the regeneration of muscles and soft tissues [10]. However, the idea of using traction to promote bone regeneration to treat bone defect only gained popularity when a Russian surgeon, Gavriil Ilizarov, developed a revolutionary surgical technique for distraction osteogenesis (DO). He implemented the law 


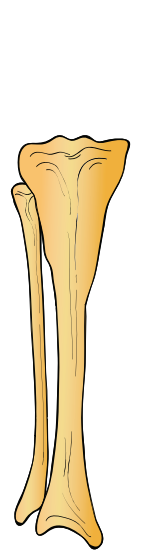

(a)

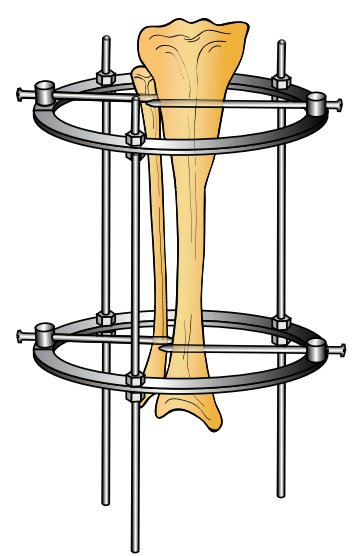

(b)

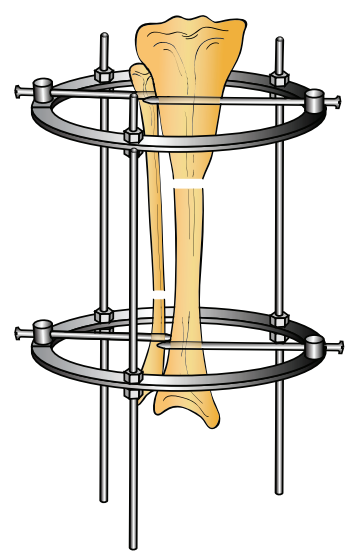

(c)

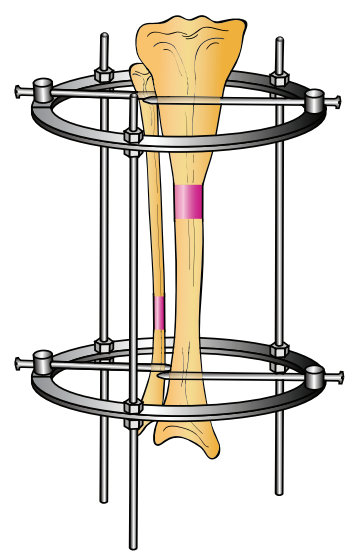

(d)

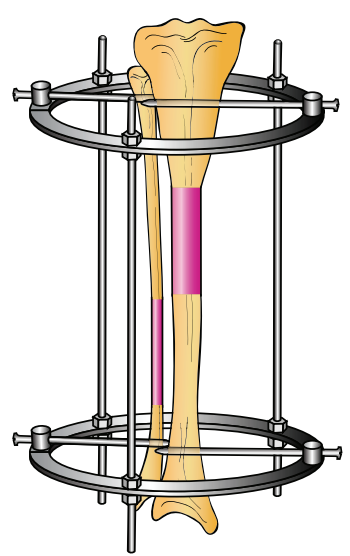

(e)

FIGURE 1: Schematic representation of distraction osteogenesis technique. (a) The tibial bone that needs lengthening. (b) Application of circular external fixator. (c) Tibial and fibular osteotomy. (d) Distraction phase and new bone formation. (e) Consolidation phase.

of tension stress and pioneered the biological principles of bone and soft tissue regeneration under slow and gradual distraction [11-13].

\section{Distraction Osteogenesis}

DO is a controlled surgical technique in which the intrinsic capacity of bone to heal and regenerate spontaneously is being used to lengthen short bones (Figure 1(a)) or to replace large segments of bone. DO consists of applying an external fixator to the affected bone in order to immobilize the proximal and distal ends of the bone providing stability (Figure 1(b)), followed by low energy osteotomy to divide the bone into two segments (Figure 1(c)). Latency phase that varies between 5 and 10 days, according to the age, is required following the osteotomy to allow the formation and organization of a hematoma and the recruitment of inflammatory cells and mesenchymal stem cells (MSCs) [14-16]. Following this phase, distraction is started and the two bone segments are gradually distracted at a rate of $1.0 \mathrm{~mm} /$ day and a rhythm of $0.25 \mathrm{~mm}$ every 6 hours until the required lengthening is attained (Figure 1(d)). Distracting more than $2 \mathrm{~mm}$ /day may lead to poor or delayed regenerated bone formation while distracting at a lower rate such as $0.5 \mathrm{~mm} /$ day leads to premature consolidation $[12,16]$. The final phase is referred to as the consolidation phase in which the distraction is ceased and the newly formed bone is allowed to mature and consolidate before the removal of the device (Figure 1(e)). This is the longest phase in $\mathrm{DO}$, requiring about one month for each centimeter lengthened [16]. Finally, the external fixator is removed once the newly formed bone is well consolidated and deemed strong enough to withstand external forces [11, $17,18]$. Figure 2 represents the different phases of DO.

\section{Types of Bone Formation Involved in Distraction Osteogenesis}

The exact mechanism and type of bone formation in DO are still being debated; however many factors have been identified to play a major role in determining which type of bone formation will predominate including stability of the fixator, rate and rhythm of distractions, and the vascularity of the surrounding tissues [14].

Three types of ossification have been described to take place during new bone formation in DO. Endochondral bone formation usually occurs at early stages of DO and it occurs external to the periosteum immediately adjacent to the fracture site where there is mechanical instability, whereas intramembranous ossification occurs at a later stage $[5,19-$ 22]. In our lab, we were able to demonstrate the presence of both types of ossification in several animal models of DO $[23,24]$. Last type is called transchondroid bone formation where chondroid bone is formed directly by chondrocyte-like cells that change gradually from fibrous tissue to bone $[5,22]$.

\section{The Molecular and Cellular Events in DO}

During the latency phase there is an inflammatory response that leads to the recruitment of MSCs and the secretion of proinflammatory cytokines (interleukin-1, interleukin-6), different growth factors such as transforming growth factorbeta (TGF- $\beta$ ), bone morphogenetic proteins (BMPs), and angiogenic factors $[5,21,25]$. These factors are responsible for recruiting MSCs and promoting them to differentiation and proliferation into chondrocytes and osteocytes. Differentiation of these cells is associated with increase expression of type 1 collagen and alkaline phosphatase $[5,8,26]$. During the distraction phase there is gradual differentiation into fibrous and fibrocartilaginous tissue that will be organized in a parallel pattern to the distraction forces [23]. This new bone starts forming from the osteotomy cuts towards the center forming a fibrous radiolucent interzone between the edges of the bone segments (Figure 3) [20, 23, 27, 28]. The fibroblast cells and collagen fibers are arranged longitudinally along the axis of distraction. In addition, during this phase all the surrounding soft tissues are lengthened at the same time with the formation of the new bone and the formation of new blood vessels with intense angiogenesis, neoangiogenesis, 


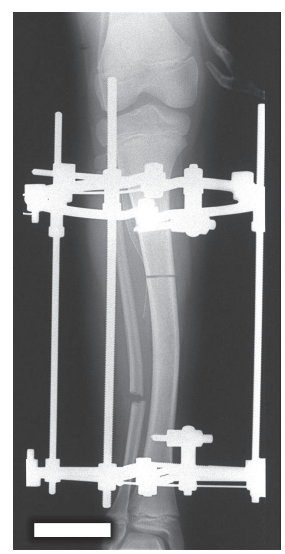

(a)

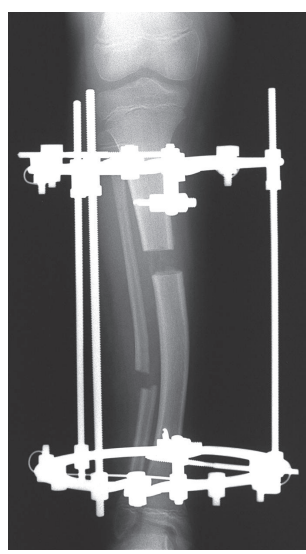

(b)

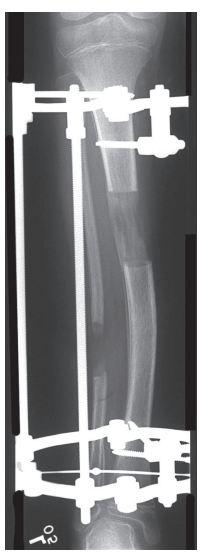

(c)

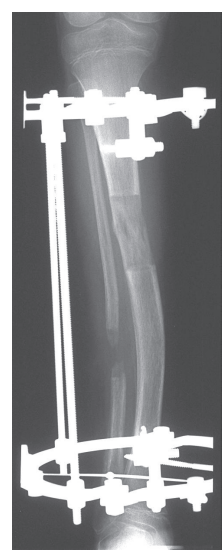

(d)

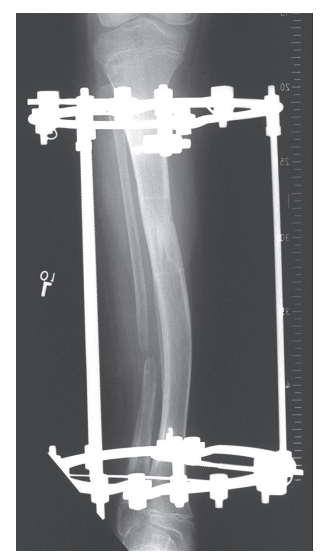

(e)

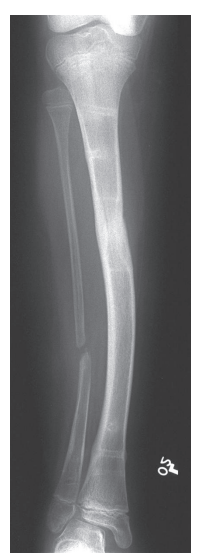

(f)

FIGURE 2: Lengthening of short tibia showing various phases of the distraction process. (a) Application of the fixator and osteotomy of the tibia. (b) Start of distraction. (c) End of distraction. (d and e) Consolidation phase, without any distraction until bone in the distracted gap consolidates. (f) Removal of the fixator (bar scale $=5 \mathrm{~cm}$ ).

and recruitment of osteoblasts $[21,29]$. DO was shown to be a vascular dependent process where multiple neoangiogenesis and angiogenesis factors are found within the distracted zone, including vascular endothelial growth factor (VEGF) and angiopoietin factors [21, 30-32]. These vascular processes occur mainly during the latency and distraction phase and then decrease gradually over time. Furthermore, as distraction progresses there is a progressive increase into the deposition of osteoblast along the periosteum and in the distracted gap that is regulated with the mechanical strain applied to the callus. New bone formation during DO is a perfect example of mechanotransduction, where the mechanical forces are converted into molecular and biochemical signals that will activate and regulate multiple cellular events such as neovascular proliferation [21], differentiation, proliferation, and secretory function of various cells including various cytokines, BMPs, extracellular matrix protein, growth factors, and even MSCs [30, 33-36]. This will help maintain the delicate balance between bone formation and bone resorption $[14,37]$. We and others have shown that the expression of various cytokines and growth factors is upregulated when exposed to the distraction forces while the same factors are downregulated when distraction is ceased. The expression of these various factors, including BMPs, Wnt signaling, insulin growth factor (IGF), fibroblast growth factor (FGF), TGF- $\beta$, platelet-derived growth factor (PDGF), and VEGF, is directly related to osteogenesis and chondrogenesis $[35,38-50]$.

\section{Advantages and Clinical Significant of DO}

Ilizarov method of DO has gained much popularity throughout the years because of its ability to produce new bone between two vascularized surfaces created by osteotomy and followed by gradual distraction [51]. It is considered to be a unique tissue engineering technique since it can spontaneously regenerate vascularized bone of the same micro- and macrostructure of the native bone in vivo without the need for bone grafts. Moreover, there are simultaneous regeneration and lengthening of the surrounding soft tissues [10]. Donor site morbidity as seen in autologous grafting is absent. DO is considered the best in vivo bone tissue engineering technique $[18,51-53]$.

\section{Disadvantages and Complications of DO}

The main disadvantage of DO is the long time the external fixator has to stay in place [54]. For every centimeter lengthened, the fixator has to be kept in place for about a month. For example, a child undergoing a $5.0 \mathrm{~cm}$ lengthening will require the fixator to be kept in place for about 5 months. This prolonged period of time can lead to multiple complications such as pin-tract infections, broken wires, and joint impairment. Moreover, applying the fixator for a long time can be cumbersome for patients and their families psychologically, socially, and financially [54-56]. Since distraction phase cannot be accelerated as this will lead to poor bone regeneration, then the question arises; how can we accelerate the consolidation phase in order to be able to remove the external fixator at an earlier time?

\section{Modalities Used in an Attempt to Accelerate DO}

Multiple modalities to accelerate bone formation in the context of DO have been described including the application of external biophysical stimuli (i.e., mechanical loading $[57,58]$, vibration [59], electrical stimulation [60, 61], extracorporeal shock wave [62, 63], and low-energy pulsed ultrasound [6466]), administration of systemic agents (i.e., sclerostin [67], calcitonin [68], bisphosphonates $[69,70]$, and prostaglandin E2 [71]), and local agents (i.e., growth factors [72, 73], BMPs [42, 44, 50, 74], scaffolds [39, 75], nanoparticles [76, 77], and osteogenic cells including autologous bone graft and MSCs $[78,79])$. In the following sections osteogenic cells, scaffolds, and growth factors will be briefly discussed and then a comprehensive review of MSCs with an emphasis on 


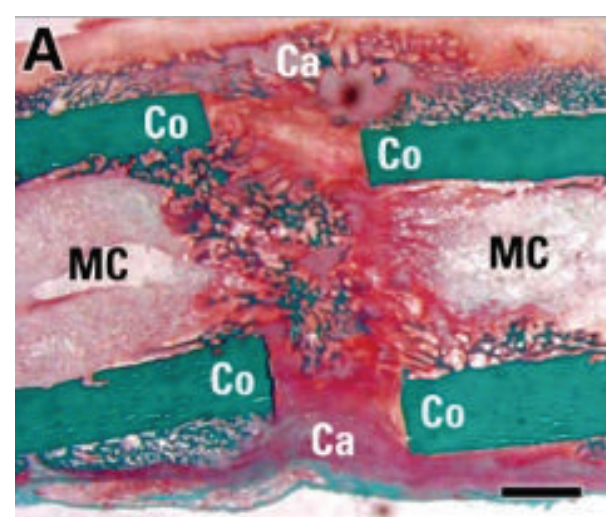

(a)

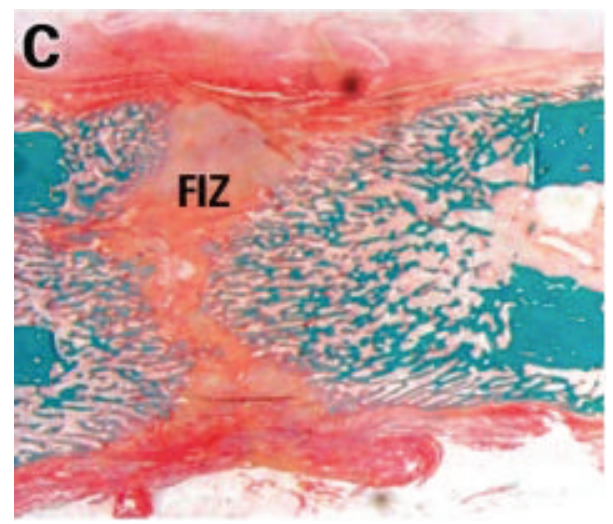

(c)

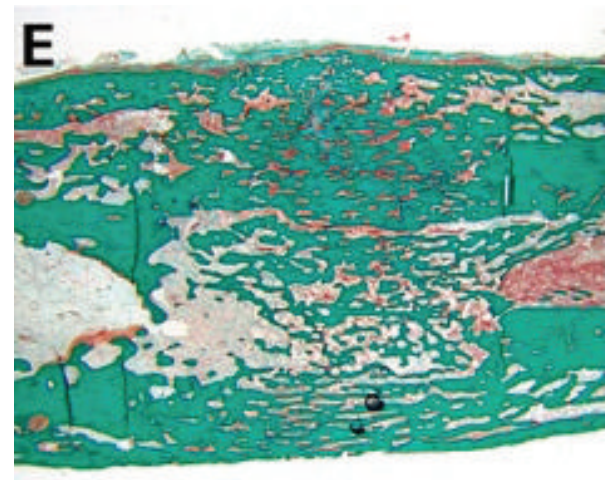

(e)

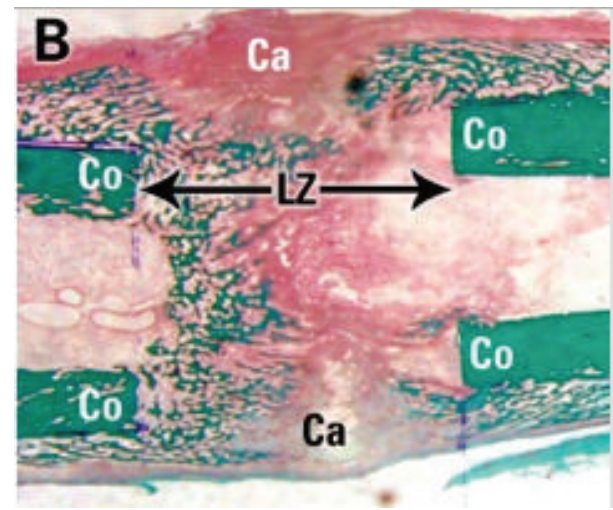

(b)

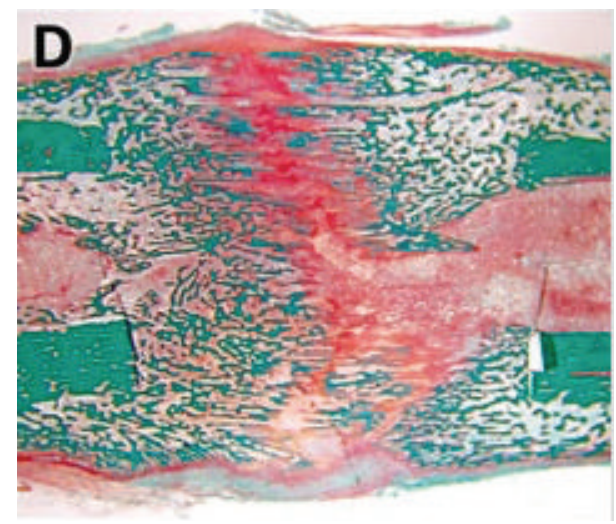

(d)

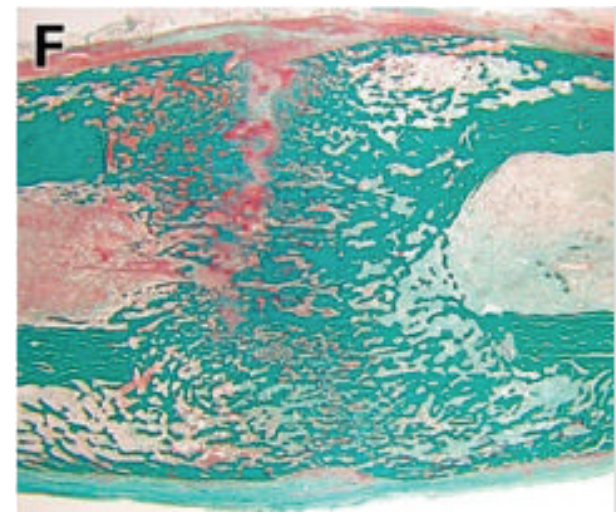

(f)

FIGURE 3: Histological changes using trichrome staining, in a rabbit DO model during distraction osteogenesis of the tibia. (a) to (c) represent the cellular change that happen during the distraction phase while (d) to (f) represent the cellular change that happen during the consolidation phase. Co: cortex; LZ: lengthened zone; Ca: callus; FIZ: fibrous interzone (bar scale $=2 \mathrm{~mm}$ ).

adipose tissue derived mesenchymal stem cells (ASCs) and their application in bone regeneration and $\mathrm{DO}$ will be done.

\section{Osteogenic Cells}

The first important element for bone regeneration is to have a source that will provide viable cells that can differentiate and proliferate into osteogenic cells. For the longest time autologous bone graft has been used and considered as the gold standard material for bone regeneration in orthopedic surgery $[8,80]$. Autologous bone is usually harvested from the anterior and posterior iliac crests of the pelvis. It can also be harvested as vascularized bone graft containing an internal vascular network in order to restore a significant bone defect $[9,81,82]$ or tricortical graft for structural support [83]. Autologous bone graft possesses many advantages including 
significant decrease in union time, high union rates, and the ability to restore critical size defects. Moreover, since it uses patient's own tissue, there is a reduction in the risk of immunoreactions and transmission of infections. Finally it possesses osteogenic, osteoconductive, and osteoinductive capacities through the bone growing cells, different proteins, and growth factors that it contains while providing a scaffold for the new bone to grow within, respectively [83]. Although autologous bone graft is a safe and effective way to provide bone cells still it has multiple limitations including donor site morbidity, limited cells quantity, requirement of a second surgical procedure with frequent consequences of pain, and complications [84-86].

An alternative method to harvest autologous bone graft is reamer irrigation aspiration (RIA) system [87]. RIA is an intramedullary reaming system that provides continuous irrigation and aspiration during intramedullary reaming. It was originally designed to decrease the adverse effects of reaming long bone fractures by collecting the reaming material which contains a significant number of osteogenic cells [88]. This provides a large volume of corticocancellous bone material that can be used as autologous bone graft. This is usually harvested from the femur [89]. This technique provides a large volume of autologous bone graft that corresponds to the bone graft obtained from both the anterior and posterior iliac crest [90]; however it still has similar limitations regarding the need for a second operation and the limited quantity of cells that can be provided.

Another methods would be allograft bone that is available in different preparation. However, allograft bone lacks osteogenic capacity as it does not contain living bone cells; therefore it is not considered to be a good source for osteogenic cells. Moreover it carries the risk of disease transmission and immunogenic responses [91]. Therefore it does not fit well with the previously mentioned concepts.

Since both autograft and allograft have restrictions, scientists have investigated the used of MSCs as mentioned above. MSCs are able to differentiate and proliferate into osteogenic cells under the appropriate molecular signals. MSCs have been found in multiple tissues including bone marrow and adipose tissues [92-95]. MSCs will be discussed in more detail in the following sections.

\section{Scaffolds}

Scaffolds are three-dimensional porous structures that need to be biocompatible and biodegradable, producing low immunogenic and antigenic reactions, and have mechanical properties similar to load-bearing bone. They provide support to the attached cells and provide space for it to proliferate (Figure 5) [96]. Scaffolds can be divided into different classes according to the materials used. These include natural polymer (e.g., collagen, fibrin, alginate, and chitosan), synthetic polymers (e.g., polylactic acid (PLA) and polyglycolic acid (PLGA)), and inorganic materials (e.g., calcium phosphates, silicate glasses, hydroxyapatite (HA), ceramics, and calcium sulfate) $[3,75,97,98]$. These materials have limitations when used on their own including brittleness (e.g., inorganic materials), inflammatory response (e.g., synthetic polymers), and immunogenicity (e.g., natural polymers), which led scientists to investigate nanocomposite scaffolds for their advantages [99]. These advantages include the ability to penetrate deep in tissues without causing damage to the surrounding cells, unique size-scale, large surface to volume ratio, the ability to provide an appropriate vehicle to direct stem cells into specific lineages, the ability to mimic the composition of the natural bone, low immunogenicity, and the ability to enhance the mechanical properties of inorganic materials [100-102]. They can be used as two-dimensional (2D) scaffolds where it covers the implants promoting bone regeneration by allowing cell attachment and tissues to grow on the implant surfaces only or three-dimensional (3D) scaffolds that allow cells to grow on the surface and within it too $[103,104]$. 3D scaffolds were found to improve proliferation, differentiation, and activity of cells that grow within them [105]. Environment that mimics the conditions found in the bone microenvironments will help the differentiation of MSCs into osteogenic lineage. This will provide the necessary signals to help MSCs to differentiate and proliferate into the osteogenic lineage in order to repair and regenerate bone. Using the nanocomposite scaffolds technology can provide this environment by providing a controlled environment to the implanted cells, help regulate delivery of nutrients and removal of waste, and enhance the direct differentiation of ASCs into the osteogenic lineage. Bone is composite of a very complex extracellular matrix that helps in maintaining the structural integrity of bone and influencing the differentiation and proliferation of stem cells into the osteogenic lineage [106, 107]. Extracellular matrix consists of organic component, composed mainly of mineralized calcium in the form of $\mathrm{HA}$ and a mixture of other inorganic salts $[106,108,109]$, and inorganic component, primary composed of $95 \%$ type I collagen and other noncollagenous proteins $[110,111]$. Therefore, it is very important to be able to provide the appropriate nanoparticle composite to induce and enhance the differentiation of ASCs into osteogenic lineage. Few studies have been done looking at different materials and their effect on ASCs. Lu studied the effect of 3D-nanocomposite scaffold composed of biphasic calcium phosphates (BCP) coated with a nanocomposite layer of polycaprolactone (PCL) and HA-nanoparticles and their effect on osteogenic differentiation of ASCs. Lu et al. were able to show that ASCs on BCP/PCL-nHA had earlier osteogenic differentiation compared with control [112]. Ghorbani and his colleague looked at a slightly different nanoparticle composite where they used PCL/Chitosan (Ch)/zincdoped HA (nZnHA) nanocomposite with ASCs. They were able to demonstrate an increase in ASCs attachment to the nanocomposite and more important significant increase in the proliferation rate of ASCs compared with control [113]. In another study by McCullen et al., they fabricated scaffolds consisting of B-tricalcium phosphate (TCP) crystals and PLA at varying loading levels of TCP $(0,5,10$, and $20 \mathrm{wt} \%)$ and assessed the composite scaffolds ability to induce proliferation and osteogenic differentiation of ASCs in vitro. In this study they were able to show that ASCs were able to adhere, proliferate, and osteogenically differentiate on all scaffolds; however there was a significant increase in the amount of cell-mediated mineralization in the highest TCP compared to 
the lowest TCP which suggest that the biochemical nature of the scaffold can accelerate and induce the overall osteogenic differentiation of ASCs [114]. In another study in vivo, they implanted PLGA/HA nanocomposite compared to PLGA scaffold only in a critical size defects in rat skulls where they found significant new bone formation with PLGA/HA in contrast with PLGA scaffold alone that had nearly no new bone formation. They concluded that the direct contact of cells with HA nanoparticles may stimulate osteogenesis [115]. There have been also some reports about other materials used and their effects on stem cells nonetheless there have not been any consensus on which nanoparticle/polymer composite is superior [97]. However the investigations that have been done till now with nanocomposite scaffolds demonstrate that such technology should be considered for bone tissue engineering application, as it will help and accelerate the differentiation and proliferation of ASCs into the osteogenic lineage leading to bone regeneration.

\section{Growth Factors}

Growth factors are usually used to enhance cell proliferation and differentiation of MSCs cells into osteogenic lineage. Multiple osteogenic growth factors were able to produce highly purified bioactive cytokines in large quantities, suitable for both cell culture and for in vivo applications. BMPs are considered to be the most promising osteogenic growth factors in stimulating bone formation and the most studied ones. They have been shown to be significantly involved with bone regeneration in fracture healing and DO as they trigger a cascade of events that lead to osteogenesis, chondrogenesis, angiogenesis, and upregulation of numerous growth factors [14]. They belong to the TGF- $\beta$ superfamily that acts on many different systems including bone. BMPs are considered to be one of the most powerful osteogenic growth factor and the only osteoinductive ones that can act on undifferentiated MSCs early on (Figure 4) [116-118].

\section{Stem Cells}

Stem cells are undifferentiated progenitor cells that are capable of both self-renewal and multilineage differentiation [119]. They are classified into two categories, depending on their origin, the embryonic stem cells (ESCs) and the adult stem cells. The ESCs are derived from the inner cell mass of blastocyst-stage embryos [120], while the adult stem cells are derived from differentiated postnatal tissues and these are believed to be intimately involved in tissue/organ regeneration and repair during injury and ageing [121]. Only ESCs are considered to be pluripotent, since they are capable of giving rise to differentiated cell lineages of all three embryonic germ layers: endoderm, mesoderm, and ectoderm [122]. However their use is very limited by ethical, legal, and political concerns. On the other hand, adult stem cells are considered to be multipotent since they have lower degree of plasticity. Previously, it was believed that adult stem cells were only capable of differentiating into lineages that are characteristic of the tissue or organ from which they originated. However, recent evidence suggests that adult stem

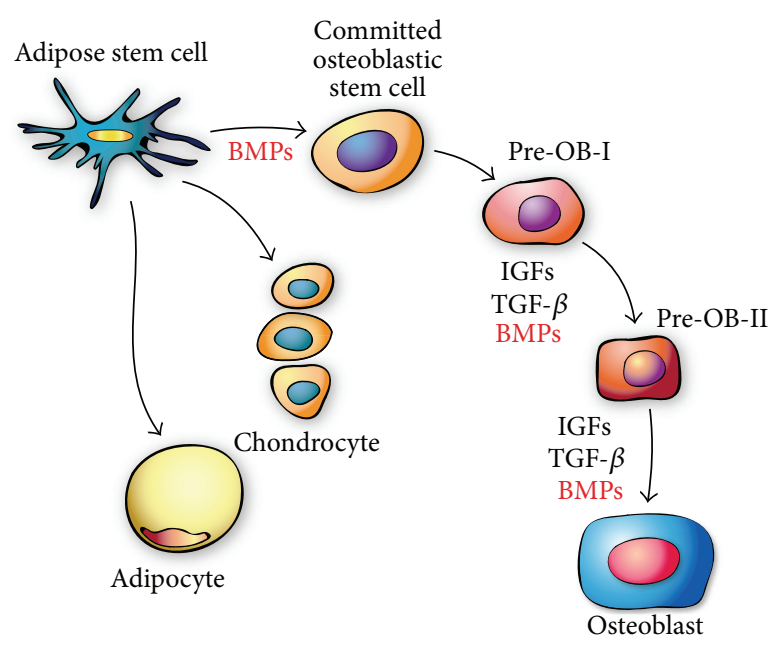

FIGURE 4: Schematic representation of BMP's effect on the differentiation of adipose stem cells into osteoblast.

cells could possess a much higher degree of plasticity than previously thought $[123,124]$.

\section{Mesenchymal Stem Cells}

MSCs were initially discovered in bone marrow, after which they were isolated and characterized from several adult and fetal tissues, including adipose tissue, dermis, periosteum, umbilical cord blood, placenta and amniotic fluid, and synovial fluid [93, 125-129]. A set of minimal criteria were put in place by the international society for cellular therapy (ISCT) in order to be able to label a cell as MSC: cells must be plastic adherent when they are maintained in standard culture conditions, and they must express CD105, CD73, and CD90, lack the expression of CD45, CD34, CD14, CD11b, CD79 $\alpha$, or CD19 and HLA-DR surface molecules, and be capable of differentiating into osteoblasts, adipocytes, and chondroblasts in vitro [130]. MSCs have significant therapeutic potentials that can be applied to multiple disciplines especially where MSCs show low immunogenicity [131-133] and can differentiate into osteoblasts, chondroblasts, and adipocytes [134-136].

\section{Bone Marrow Derived Mesenchymal Stem Cells (BM-MSCs)}

MSCs were originally isolated from bone marrow by Friedenstein et al. [137], which have been considered the main source for MSCs for long time [138]. Bone marrow aspirates are collected from the iliac crest and MSCs are isolated and then cultivated. However, this is a painful and invasive procedure that often results in low yield of MSCs, especially that MSCs are present in relatively small quantities in the bone marrow and constitute about $0.001 \%-0.01 \%$ of the total marrow nucleated cells. Moreover, their ability to proliferate and differentiate declines after extensive passage or with age $[93,125,138]$. These disadvantages urged scientists to search for other sources of MSCs including adipose tissue. 


\section{Adipose Derived Mesenchymal Stem Cells}

ASCs where first isolated from human adipose tissue in 1976 [139], but they were not identified and characterized until 2001 [94]. Zuk et al. studied extensively the isolated ASCs from human lipoaspirates, and they showed that one gram of adipose tissue yields approximately $5 \times 10^{3}$ stem cells, which is 500 -fold greater than the number of MSCs in one gram of bone marrow indicating that adipose tissues are rich with MSCs and can be used as a promising alternative source for BM-MSC [140-143]. Over the last few years, several reports have shown that ASCs possess several advantages when compared to BM-MSCs. First, ASCs are readily available in large quantities, almost unlimited [141, 144], and can be retrieved in high volumes of cellular population with less invasive methods such as liposuction aspirates or subcutaneous adipose tissue fragments [94]. Moreover, ASCs can easily be expanded in vitro, have an extensive self-renewal capacity [95], and are easily isolated in a laboratory setting by differential sedimentation $[94,145,146]$. ASCs like BM-MSCs can differentiate into various cells, including adipocytes, osteoblasts, and chondrocytes (Figure 5) [134, 147].

\section{Isolation of Mesenchymal Stem Cells from Adipose Tissue}

Adipose tissue is comprised of adipocytes and a heterogeneous set of cell populations including endothelial cells, endothelial progenitor cells, pericytes, and erythrocytes that surround and support them, which upon isolation are termed the stromal vascular fraction (SVF) [142, 148, 149]. In order to isolate ASCs, adipose cells are harvested and then minced and digested by collagenase type II [145]. Then the SVF is separated by centrifugation as it has a higher density than the adipocytes $[141,145]$. Later on, ASCs are isolated from the SVF by plastic adherence in culture, which can easily be cultured and expanded in vitro $[145,149,150]$. Moreover, isolated ASCs can be cryopreserved in a media of serum and dimethyl sulfoxide without losing their ability to differentiate and proliferate [151].

\section{Adipose Stem Cells Immunophenotype}

In order to be able to characterize ASCs and confirm that they abide with the ISCT guidelines, flow cytometry is used to determine the presence of specific cell surface markers. Since ASCs are not of homogenous population, there have been multiple attempts to find a unique single marker however that is still yet to be identified [95, 135, 152]. ASCs do express the typical MSCs markers such as CD13, CD29, CD44, CD63, CD73, CD90, and CD105, and ASCs show negative expression of for hematopoietic antigens such as CD14, CD31, CD45, CD 34, CD144, and HLA-DR [141, 142, 149, 153]. Some other markers are present at the beginning but do disappear or are lost during the different passaging while other will increase, as passaging will select more homogenous population with more homogenous cell surface markers [153-155]. Moreover, ASCs population included four groups with their own cell surface markers. The main two groups are preadipocytes

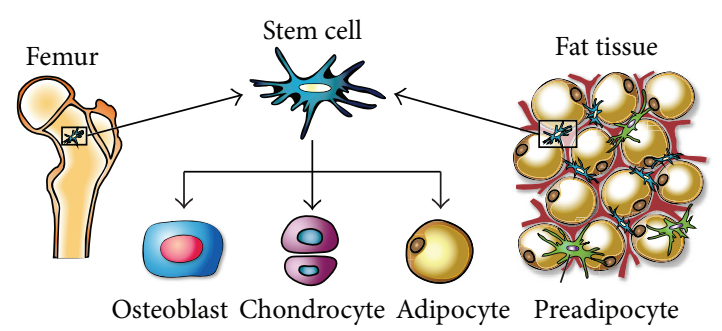

FIGURE 5: Schematic representation of stem cell isolation sites. This schematic shows that adult stem cells can be found in both bone marrow and adipose tissue. Both BM-MSC and ASC are capable of differentiating into the same three lineages' osteoblast, chondrocyte, and adipocyte.

cells, which represent $67.7 \%$ of the population and express $\mathrm{CD} 31^{-} / \mathrm{CD} 34^{+}$surface markers, and premature endothelial cells which represent $5.2 \%$ and express $\mathrm{CD} 31^{+} / \mathrm{CD} 34^{+}$. The other two groups represent less than $1 \%$ and they are pericytes cells, $\mathrm{CD} 146^{+} / \mathrm{CD} 31^{-} / \mathrm{CD} 34^{-}$, and the mature endothelial cells, CD $31^{+} / \mathrm{CD} 34^{-}[152,156,157]$. ASCs have the ability to secrete growth factors such as FGF, VEGF, IGF, and TGF- $\beta 1$ that stimulate and help tissue regeneration $[158,159]$. Also, they are sensitive to different growth factors such FGF, PDGF, and VEGF [160]. This rendered ASCs ideal candidate for tissue engineering and bone regeneration.

\section{Techniques for Direct ASCs Differentiation}

17.1. Culture Milieu for ASCs Differentiation In Vitro. An important characteristic of ASCs is their ability to differentiation into multiple lineages, in particularly chondrocytes, osteocytes, and adipocytes, when the correct conditions are provided $[123,135,146,149]$. The induction of ASCs differentiation in vitro is achieved by culturing ASCs in specific media [145]. Table 1 shows the different medias used for the induction of adipocytes, osteocytes, and chondrocytes.

17.2. The Use of Physical Stimuli to Differentiate MSCs into Osteoblasts. Another less well-explored practice to differentiate stem cells is the application of physical stimuli including mechanical forces, magnetic, and electrical fields (Figure 6). Mechanical load has been identified as an essential factor in the development and maintenance of bone architecture and integrity $[166,167]$. Increasing mechanical load leads to increase in bone mass by stimulating bone formation and inhibiting bone resorption through the activation of osteoblast cells and decreasing the activity of osteoclasts cells [168]. The process by which cells convert physical stimuli into biochemical response is called mechanotransduction [37, 169]. Mechanotransduction of stem cells is a very complex process that involves multiple signaling pathways that are not fully understood yet [167]. There have been few studies done to study the effect of mechanical stimuli on MSCs in vitro [170-174] and in animal models [175, 176], mainly on BM-MSCs [167]. Kapur et al. demonstrated the existence of multiple signaling pathways for stimulating osteoblast proliferation and differentiation from MSCs in response 
TABLE 1: Required supplements to induce differentiation of ASC into different lineages.

\begin{tabular}{|c|c|c|c|c|}
\hline Cell lineage & Serum/media & Supplement required & Lineage characterization & $\begin{array}{l}\text { Histologic/immunohistochemistry } \\
\text { assay }\end{array}$ \\
\hline Adipocytes $[144,149,161]$ & $\begin{array}{l}\text { (1) DMEM } \\
\text { (2) } 10 \% \text { FBS }\end{array}$ & $\begin{array}{l}\text { (1) Isobutylmethylxanthine } \\
\text { (2) Insulin } \\
\text { (3) Dexamethasone } \\
\text { (4) Indomethacin }\end{array}$ & (1) Lipid accumulation & $\begin{array}{l}\text { (1) Oil red O stain } \\
\text { (2) Sudan III stain }\end{array}$ \\
\hline Osteocytes $[144,149,162]$ & $\begin{array}{l}\text { (1) DMEM } \\
\text { (2) } 10 \% \text { FBS }\end{array}$ & $\begin{array}{l}\text { (1) 1,25-Dihydroxyvitamin } \\
\text { (2) } \beta \text {-glycerophosphate } \\
\text { (3) Ascorbate-2-phosphate } \\
\text { (4) Dexamethasone }\end{array}$ & $\begin{array}{l}\text { (1) Alkaline phosphatase } \\
\text { activity } \\
\text { (2) Production of calcified } \\
\text { matrix }\end{array}$ & $\begin{array}{l}\text { (1) Alizarin red stain } \\
\text { (2) Von Kossa stain }\end{array}$ \\
\hline Chondrocyte [163-165] & $\begin{array}{l}\text { (1) DMEM } \\
\text { (2) } 1 \% \text { FBS }\end{array}$ & $\begin{array}{l}\text { (1) TGF- } \beta 1 \\
\text { (2) Insulin } \\
\text { (3) Dexamethasone } \\
\text { (4) Ascorbate-2-phosphate } \\
\text { (5) BMP-6 }\end{array}$ & $\begin{array}{l}\text { (1) Sulfated proteoglycan } \\
\text { rich matrix } \\
\text { (2) Synthesis of collagen II }\end{array}$ & $\begin{array}{l}\text { (1) Alcian blue stain } \\
\text { (2) Collagen type II monoclonal } \\
\text { antibodies }\end{array}$ \\
\hline
\end{tabular}

DMEM: Dulbecco's Modified Eagle's Medium, FBS: fetal bovine serum, BMP-2: bone morphogenetic protein-2, BMP-6: bone morphogenetic protein-6, and TGF- $\beta 1$ : tissue growth factor.

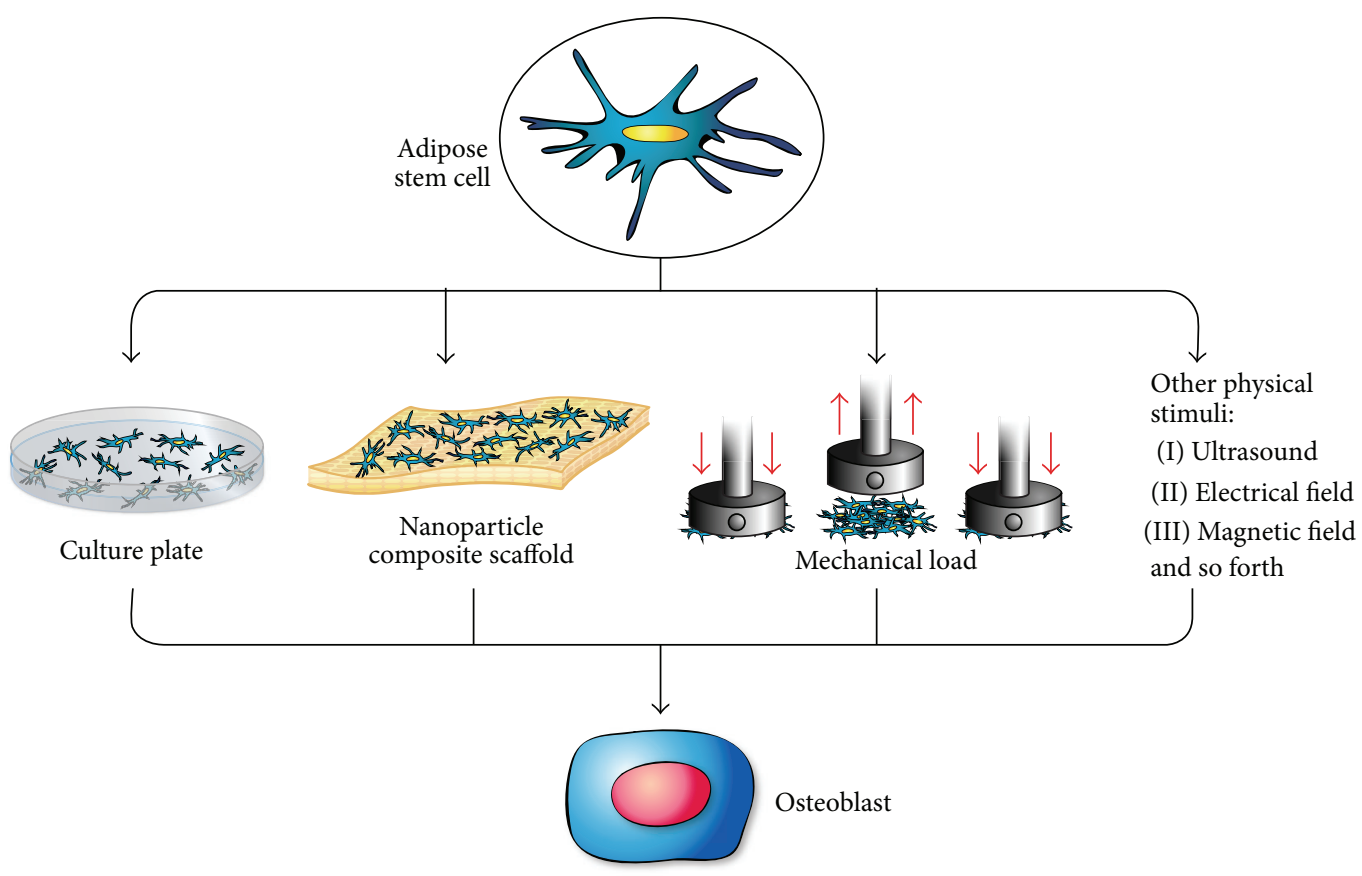

FIGURE 6: Schematic representation of different stimulating factors that can affect the differentiation of adipose stem cells into osteoblast.

to mechanical stimuli. Mechanical stimuli can be applied either in the form of cyclic stretch $[173,177,178]$ or in the form of fluid shear flow [179-182]. Duncan and Turner were able to show that shear stress causes primary and clonal osteoblast-like cells to proliferate and differentiate leading to increase in bone formation [183]. Also, Yoshikawa et al. were able to show that mechanical stimulation promotes the differentiation of osteogenic cells and enhances bone formation in vitro [172]. Moreover Altman et al. were able to show the differentiation of MSCs into osteogenic lineage under mechanical stimulus alone and without any exogenous growth factors [170]. Another source of physical stimuli is the application of electrical field that was shown to stimulate osteogenic differentiation from stem cells $[184,185]$.
The effect of pulsating electrical fields on osteogenesis has been studied in both animal models and in vitro studies and showed that it enhances stem cell signaling pathways and differentiation by modulating intracellular calcium signaling and augmenting tissue-specific markers [186, 187]. Recently, Hammerick was able to demonstrate an enhancement in early osteogenic markers in mouse ASCs using electrical field via ionic salt bridges; however there was no change in terminal differentiation [188]. Also, McCullen et al. studied the effect of sinusoidal alternating current electric fields on ASCs and demonstrated significant increase in intracellular calcium [189]. Other modalities are currently being investigated including magnetic fields [190, 191], ultrasound [192, 193], and laser irradiation $[194,195]$. All these mechanical stimuli 
provide practical and promising methods to accelerate and facilitate the differentiation and proliferation of MSCs into osteogenic lineage cells that would be extremely significant in bone regeneration and tissue engineering.

\section{BM-MSCs versus ASCs}

Few studies were conducted to compare the characteristic differences between BM-MSCs and ASCs. Rebelatto et al. [134] have shown that both BM-MSCs and ASCs are morphologically and immunophenotypically similar expressing CD44, CD105, CD90, and CD73 and not expressing CD34, CD45, and HLA-DR. Moreover, both can differentiate into tissues of mesodermal and nonmesodermal origins. Strioga et al. compared the ontology and biology and preclinical and clinical application of ASCs and BM-MSCs [92]. They showed that both BM-MSCs and ASCs share many biological characteristics. However, some differences in their immunophenotype, differentiation potential, transcriptome, proteome, and immunomodulatory activity do exist and these differences may represent specific features of BM-MSCs and ASCs and inherent heterogeneity, simply due to the different isolation and culture protocols [92]. Nevertheless, ASCs are as effective as BM-MSCs in clinical applications. In fact ASCs are gaining the upper hand in clinical translational setting and stem cell-based tissue engineering. Table 2 summarizes the major differences between BM-MSCs and ASCs.

\section{Clinical Applications of ASCs in Bone Regeneration and DO}

Bone regeneration represents a complex physiological and biological process that involves multiple cells recruitment and various signaling molecules and pathways that repair and regenerate bone in response to injury. In order for this complex mechanism to maximize its efficiency there are some requirements that have been identified including osteogenic cells, osteoconductive systems, and osteoinductive growth factors. This triangle concept represents an emerging stateof-the-art science and bone tissue engineering. This evolutionary science aims to repair a failing bone organ $[3,196]$.

However Giannoudis et al. have took this concept and modified into the diamond concept, which acknowledges the importance of implanting osteogenic cells in osteoconductive scaffolds and adding the essential growth factor in order to promote bone regeneration [197]. However, they emphasized the importance of two other factors that need to be addressed prior to any implantation or intervention. These factors are the optimization of the nonunion bed of the host in terms of adequate vascularization and the presence of adequate mechanical stability that will provide an appropriate environment for the cells to interact with the scaffold and growth factors in order to promote successful osteogenesis $[198,199]$. For the purpose of this paper we have briefly discussed osteogenic cells including ASCs, scaffolds, and growth factors. The implication of ASCs in bone regeneration and DO will be summarized in the following paragraph.
Table 3 represents a summary of all the recent studies performed on ASCs in cases of DO and bone CSDs with the exception of maxillary/mandibular studies.

Liu et al. were the first to show that allogeneic ASCs combined with coral scaffolds are able to regenerate bone in critical-size defect model [204]. Cowan et al. introduced ASCs with PGLA scaffolds into CSD of mouse calvarial and had a significant increase in intramembranous bone formation by the end of two weeks and a complete bridging by 12 weeks without using any growth factors [205]. One study combined the benefits of using growth factors like BMP-2 with ASCs, where bone regeneration in calvarial CSD was enhanced [214]. Di Bella et al. reported that isolated autologous ASCs from rabbits implanted with osteoinduction fibronectincoated porous cylindrical scaffolds improved bone regeneration in a critical-sized skull defect of rabbits [206]. On the clinical side, Lendeckel and colleagues described in a case report the use of autologous ASCs, bone graft, and fibrin glue all isolated from the patients tissue which were combined to treat cranial CSD in a young girl [207]. Three-month followup CT scan showed almost complete calvarial healing. All the previously mentioned studies concluded that ASCs can differentiate into osteoblasts with the capacity to regenerate bone and heal CSDs, this indicates that ASCs can be used as an alternative to bone graft in treating bone defects.

Studies describing the use of BM-MSCs or ASCs during DO are scarce in the literature. BM-MSCs were shown to accelerate new bone formation in DO models with shortened consolidation period [215]. Nomura et al. introduced ASCs mixed with collagen gels in rats after performing DO [208]. The research group observed an increase in bone formation in the ASC-Collagen injected rats compared to the control, and analysis of the formed callus showed both osteogenic differentiation and secretion of growth factors, which proves that ASCs promoted the formation of new bone. The therapeutic potentials of ASCs in tibial defects managed by DO were investigated in rabbits [209]. Radiologic analyses showed an increase in callus density, with increased ossification rate, in rabbits treated with osteoblast differentiated-ASCs compared to the control group treated with undifferentiated-ASC; they concluded that osteoblasts-differentiated ASCs shorten the consolidation period of DO [209]. In conclusion using ASCs instead of BM-MSCs ensure the availability of stem cells in abundance through a minimal invasive method without imposing any morbidity to the donor. Moreover, ASCs ability to regenerate bone in DO will accelerate the process and decrease the consolidation phase leading to an early removal of the fixator, which in return will decrease complications associated with DO such as infection, nonunion, psychological, and financial burden.

\section{Perspectives and Challenges}

Large bone defects continue to pose a formidable challenge to healing physicians. DO has been a very successful technique that is being used worldwide to treat multiple orthopedic and craniofacial complex conditions. However, as mentioned before, one major limitation is the long time the fixator needs to be kept in place until consolidation is done. Multiple 
TABLE 2: Difference between BM-MSC and ASC.

\begin{tabular}{|c|c|c|}
\hline Characteristics & BM-MSC & ASC \\
\hline Stem cells isolation procedure $[38,41]$ & Invasive, complex & Noninvasive, simple \\
\hline $\begin{array}{l}\text { The availability of stem cells in a given volume of BM aspirates or liposuction } \\
\text { aspirate }[41,42]\end{array}$ & Low & Abundant \\
\hline Effect of donor's age on stem cell differentiation capabilities [36] & Decrease & Same \\
\hline Site of collection $[38,41]$ & Iliac crest & Any fat tissue \\
\hline Quantity available $[41,42]$ & Limited & Infinite \\
\hline Differentiation $[27,28]$ & $\begin{array}{l}\text { Adipocytes, osteocytes, } \\
\text { chondrocytes }\end{array}$ & $\begin{array}{l}\text { Adipocytes, osteocytes, } \\
\text { chondrocytes }\end{array}$ \\
\hline Immunogenicity [26] & Low & Low \\
\hline
\end{tabular}

methods and modalities have been used to accelerate the consolidation phase including the application of ASCs. As discussed above, ASCs fulfill most of the requirements needed for tissue engineering as they are available in an abundant quantities, can supply large number of cells, are easily accessible, have low immunogenicity, and are able to differentiate into multiple lineages and easy to isolate and expand in vitro [144]. ASCs have the potential to be used in the treatment of acute and chronic musculoskeletal disorders and other conditions. The Food and Drug Administration needs to approve the use of ASCs in bone regeneration and DO before it can be considered as a standard treatment. This will require significant preclinical research and development, some of which is outlined below.

ASCs are usually expanded and induced into osteogenic lineage using fetal bovine serum (FBS) medium. FBS medium is an animal derived product that can, theoretically, cause transmission of prions and bacterial or viral infections, even though it is very small [216] and increases the risk of immune reactions in the host to the xenogeneic materials used [217]. In order to overcome this problem, FBS free defined medium needs to be developed, optimized, and standardized. Few studies have already compared the use of human autologous serum to FBS on both ASCs and BM-MSCs and showed that human autologous serum produces comparable morphology, immunophenotype, and proliferation and differentiation capacity to FBS [148, 217-220]. Another alternative is allogeneic human serum that also showed promising results [221]. Therefore establishing and optimizing a safe and rapid expansion protocol for ASCs based on xeno-free culture are essential for cell-based therapies such as tissue engineering and regenerative medicine.

Also well-defined protocols for osteogenic differentiation from ASCs are needed for cell-based therapy. As discussed before there are multiple studies that have been done on this topic; however there has not been any consensus yet. Osteogenic differentiation may be enhanced if various techniques were combined together instead of being used alone. Therefore, combining the usually used culture media and supplementing it with growth factors such as BMPs and then allowing it to undergo some kind of physical stimuli might provide the optimal conditions required for osteogenic differentiation. This has not been studied enough yet but hopefully will be in the near future.
Another important area that needs to be clarified before taking any clinical testing is the potential tumorigenic feature of ASCs. There is a significant controversy in the current literature about the effect of ASCs on tumor growth as some studies showed that ASCs may favor the growth of tumor cells while other studies contradicted these results [222-225]. Yu et al. have shown that coinjection of human ASCs (hASCs) with tumor cells into BALB/c nude mice had increased the tumor cell viability in vivo and reduced the apoptotic cell death therefore favoring tumor growth in vivo [225]. Muehlberg et al. have also shown that mouse ASCs cause a significant rapid growth in cancer when added to murine breast cancer cell line. Moreover they showed that ASCs play an important role in tumor metastasis [223]. On the other hand, Cousin and his colleagues have shown that ASCs strongly inhibit pancreatic ductal adenocarcinoma proliferation both in vitro and in vivo. Moreover, ASCs induce tumor cell death [224]. Also Grisendi and colleagues have shown that ASCs can be used to support tumor necrosis factor related apoptosisinducing ligand (TRAIL), which is a proapoptotic ligand that induces apoptosis in a variety of human cancers but not normal cells [226]. Hence, the literature is contradictory on the implication of ASCs in tumor growth and that can be partially explained by the different protocols used both in vivo and in vitro, which makes it hard to compare them. As in some studies, they combined ASCs injection with tumor cells while others did not. Moreover, different sources of ASCs were used including human and mouse ASCs and different types of cancers cells were investigated. To our knowledge, there are no studies which have been done to investigate the effect of ASCs on bone cancer. Thus, it is necessary to conduct more studies with consensual protocols to study the tumorigenic feature of ASCs and the long-term safety of using this technique before ASCs can be used as therapeutic tools in regenerative medicine and $\mathrm{DO}$.

Another area of interest is the use of ASCs in DO. To date the scarce executed studies discussing the use of ASCs in DO did not provide a guideline with precise stepwise protocol of application of ASCs in DO model. From a therapeutic point of view, the use of ASCs should be carefully described according to the type of bone defect and callus shape. Donnan et al. classified callus depending on the shape, polarity, and consistency of callus regeneration [227]. Then Halvorsen et al. [162] described another classification based 
TABLE 3: Overview of the studies performed on bone regeneration and distraction osteogenesis using ASC.

\begin{tabular}{|c|c|c|c|c|}
\hline Author & Cell type & Scaffold & Model & Observation \\
\hline \multicolumn{5}{|c|}{ ASC's application with scaffolds, without the use of growth factors } \\
\hline $\begin{array}{l}\text { Yoon et al. } \\
{[200]}\end{array}$ & $\begin{array}{l}\text { ASC \& } \\
\text { d-ASC }\end{array}$ & PLGA & Calvarial CSD in rats & $\begin{array}{l}\text { d-ASCs with PGLA have better bone regeneration capability } \\
\text { in CSD than constructs with ASC alone }\end{array}$ \\
\hline Cui et al. [201] & ASC & Coral & Calvarial CSD in dogs & $\begin{array}{l}\text { Bone was almost completely restored in the CSD, when ASCs } \\
\text { were applied. Minimal bone formation with fibroid tissues } \\
\text { was observed in the control group }\end{array}$ \\
\hline $\begin{array}{l}\text { Carvalho et al. } \\
{[202]}\end{array}$ & ASC & SPCL & Calvarial CSD in mice & $\begin{array}{c}\text { Nondifferentiated human ASCs enhance ossification of } \\
\text { nonhealing mice CSD }\end{array}$ \\
\hline $\begin{array}{l}\text { Schubert et al. } \\
\text { [203] }\end{array}$ & d-ASC & $\begin{array}{l}\text { 3D osteogenic } \\
\text { ASC }\end{array}$ & $\begin{array}{l}\text { (1) Four-level spinal } \\
\text { fusion in pigs } \\
\text { (2) Femur CSD in pigs }\end{array}$ & $\begin{array}{l}\text { In a spine fusion model, applying } 3 \mathrm{D} \text { d-ASC demonstrated a } \\
\text { significant increase in bone formation } \\
\text { In the femoral CSD model, the 3D d-ASC achieved new bone } \\
\text { formation and fusion in a poorly vascularized fibrotic } \\
\text { environment }\end{array}$ \\
\hline Liu et al. [204] & $\begin{array}{l}\text { Al-ASCs, } \\
\text { Au-ASC }\end{array}$ & Coral & Cranial CSD in dogs & $\begin{array}{l}\text { Allo-ASC transplantation did not induce a systemic immune } \\
\text { response and was able to repair the cranial CSDs in an } \\
\text { analogous way to that of the autologous cells }\end{array}$ \\
\hline $\begin{array}{l}\text { Cowan et al. } \\
{[205]}\end{array}$ & ASC & PGLA & Calvarial CSD in mice & $\begin{array}{c}\text { ASC showed a significant intramembranous bone formation } \\
\text { by } 2 \text { weeks and complete bridging by } 12 \text { weeks without any } \\
\text { additives }\end{array}$ \\
\hline $\begin{array}{l}\text { Di Bella et al. } \\
\text { [206] }\end{array}$ & $\begin{array}{l}\text { ASC, } \\
\text { d-ASC }\end{array}$ & $\begin{array}{c}\text { PLA } \\
\text { \& FPLA }\end{array}$ & Skull CSD in rabbits & $\begin{array}{l}\text { (1) FPLA as a fibronectin-coated scaffold promotes bone } \\
\text { formation more than using PLA alone } \\
\text { (2) d-ASCs combined with FPLA enhance bone formation } \\
\text { significantly when compared with ASC alone }\end{array}$ \\
\hline $\begin{array}{l}\text { Lendeckel et } \\
\text { al. [207] }\end{array}$ & ASC & $\begin{array}{l}\text { Fibrin glue \& } \\
\text { bone graft }\end{array}$ & $\begin{array}{l}\text { Cranial CSD in a } \\
7 \text {-year-old girl }\end{array}$ & Complete calvarial healing after 3 months \\
\hline $\begin{array}{l}\text { Nomura et al. } \\
{[208]}\end{array}$ & ASC & Collagen gel & DO femur in rats & $\begin{array}{l}\text { ASC promoted bone formation in the distracted callus and } \\
\text { shortening the consolidation phase }\end{array}$ \\
\hline $\begin{array}{l}\text { Sunay et al. } \\
\text { [209] }\end{array}$ & $\begin{array}{l}\text { ASC, } \\
\text { d-ASC }\end{array}$ & & DO tibia in rabbits & $\begin{array}{l}\text { d-ASC showed increase in the callus density and the } \\
\text { ossification rate compared to the undifferentiated ASC. The } \\
\text { quality of bone formed within the callus was significantly } \\
\text { enhanced. Use of d-ASC can shorten the consolidation } \\
\text { period of distraction osteogenesis }\end{array}$ \\
\hline $\begin{array}{l}\text { Arrigoni et al. } \\
{[210]}\end{array}$ & ASC & HA & Tibia CSD in rabbits & $\begin{array}{l}\text { ASCs-HA constructs improved bone healing significantly, } \\
\text { when compared to using scaffold alone }\end{array}$ \\
\hline $\begin{array}{l}\text { Cheng et al. } \\
\text { [211] }\end{array}$ & ASC & DBM & Calvarial CSD in rabbits & $\begin{array}{l}\text { New bone formation was documented in bone defects } \\
\text { transplanted with DBM-ASCs composites }\end{array}$ \\
\hline \multicolumn{5}{|c|}{ ASC's application with scaffolds, with the use of growth factors like BMP2 and TGF $(\beta 3)$} \\
\hline Lin et al. [212] & $\begin{array}{l}\text { BMP2 } \\
\text { expressing } \\
\text { ASC and } \\
\text { TGF }(\beta 3)\end{array}$ & $\begin{array}{l}\text { PLGA or gelatin } \\
\text { sponge }\end{array}$ & Calvarial CSD in rabbits & $\begin{array}{l}\text { Gelatin sponges and apatite coated PLGA were compared as } \\
\text { scaffolds. Gelatin scaffold stimulated the bone healing more } \\
\text { than apatite coated PLGA, regardless of BMP2 or TGF- } \beta 3 \\
\text { expression. The ASCs/gelatin expressing BMP2 triggered } \\
\text { better bone healing than ASCs/gelatin expressing TGF- } \beta 3\end{array}$ \\
\hline $\begin{array}{l}\text { Peterson et al. } \\
\text { [213] }\end{array}$ & $\begin{array}{l}\text { HPLA, with } \\
\text { BMP-2 } \\
\text { carrying } \\
\text { adenovirus }\end{array}$ & CCC & Femur CSD in rats & $\begin{array}{l}\text { HPLA cells genetically modified by adenoviruses, } \\
\text { overexpressing BMP-2, can induce bone formation in vivo } \\
\text { and heal CSD in rat femurs }\end{array}$ \\
\hline
\end{tabular}

Levi et al. [214] $\begin{gathered}\text { Human ASC, } \\ \text { with BMP-2 }\end{gathered}$ PGLA Calvarial CSD in mice

(1) Human ASCs ossify CSD without the need for
predifferentiation

(2) rBMP-2 was observed to increase human ASC osteogenesis in vitro and osseous healing in vivo

GF: growth factor, PLGA: polylactide-co-glycolic acid, d-ASC: differentiated ASC, PLA: polylactic acid, SPCL: wet-spun starch polycaprolactone, AlloASC: allogeneic ASC, Au-ASC: autologous ASC, FPLA: fibronectin-treated PLA, HPLA: human processed lipoaspirate, CCC: collagen-ceramic carrier, HA: hydroxyapatite, and DBM: demineralized bone matrix. 


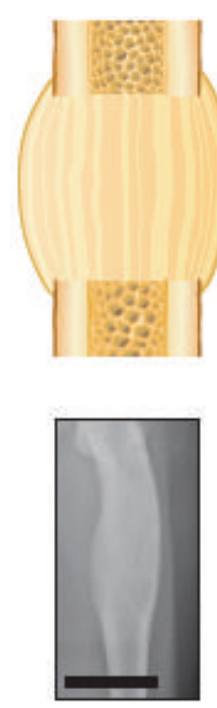

(a)
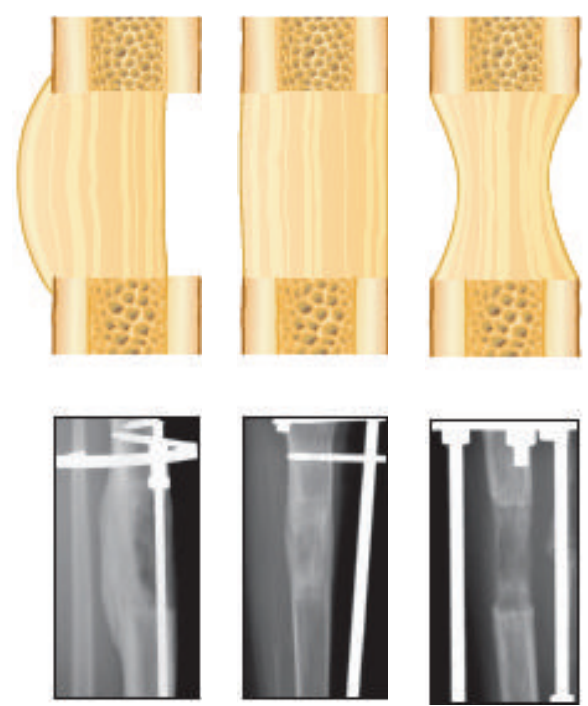

(b)

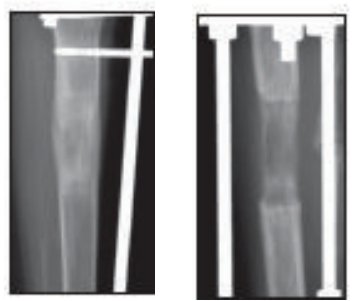

(c)
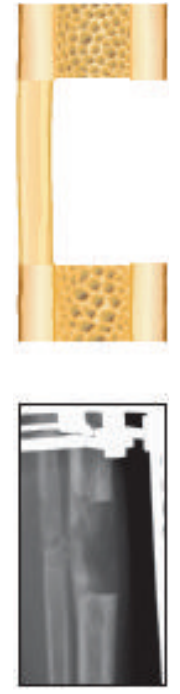

(e)
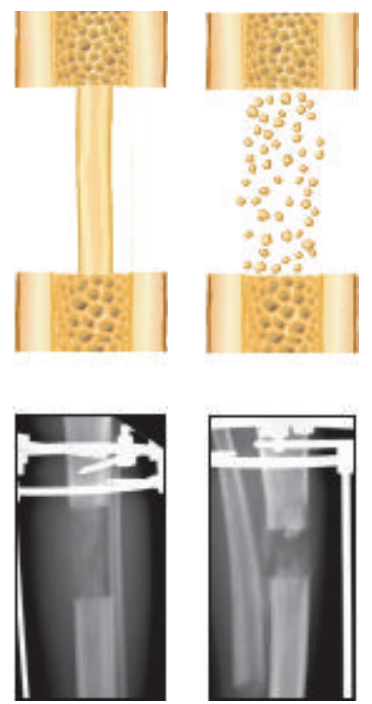

(f)

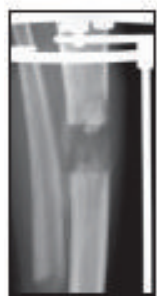

(g)

Figure 7: Representation of callus classification. Illustration and radiographs demonstrate the modified Li classification of callus shape in distraction osteogenesis. (a) New bone formation in the distraction gap extends beyond the outer borders of the cortical bone. (b) New bone formation toward one side of the distraction gap with extension beyond the outer borders of the adjacent cortical bone. (c) New bone formation within the distraction gap with margins parallel to the adjacent cortical bone. (d) Biconcave-shaped new bone formation within the distraction gap. (e) New bone formation limited to one side of the bone without extension beyond the outer borders of the cortical bone. (f) New bone formation in the center with limited new bone regeneration in the lateral portion of the distraction gap. (g) Only speckled bone formation is present (bar scale $=5 \mathrm{~cm}$ ).

on callus shape and radiographic features which also was not used clinically due to its complexity. Finally Hamdy and McCarthy [228] developed a simplified version of $\mathrm{Li}$ classification that included seven callus shapes. Figure 7 shows in detail the classified callus shapes, and Figures 7(a) through 7 (c) show satisfactory regenerated bone that should heal without squeal; therefore no addition procedures are needed. Figure $7(\mathrm{~d})$ suggests that the rate of distraction is too fast, which can be easily corrected. However, Figures 7(e) through $7(\mathrm{~g})$ are examples of poorly formed regeneration that may require enhancement before fixator removal to minimize complications. In order to improve the treatment outcome in these situations, the potential use of ASCs in bone engineering should be explored. Theoretically, in cases of partial/complete absence of bone formation in DO, the local administration of nanofibrous scaffolds with ASCs should be able to enhance and stimulate bone regeneration (Figures $7(\mathrm{e})$ and $7(f))$. On the other hand nanocomposite scaffolds should be used in combination with ASCs to provide mechanical and biological support when there is suboptimal callus formation in DO (Figure $7(\mathrm{~g})$ ). To the best of our knowledge there have not been any previous studies investigating this promising strategies in the context of ASCs and DO.

Optimizing the concentrations of ASCs, mode of delivery and the time of application need to be extensively investigated in order to use this technology in DO and CSDs. It is important to validate if ASCs should be injected at the beginning, midway, or the end of distraction as this can have different impact on callus formation, the efficiency of ASCs proliferation, and differentiation. Moreover, the optimal concentration was never investigated before and such studies will be important to standardize a reproducible controlled guideline, to be used in clinical translational approaches.

Tissue engineering on bone regeneration as mentioned above requires scaffolds, growth factors and osteogenic cells. In DO the application of exogenic biological agents including growth factors has been a very-well documented approach to accelerate bone regeneration; however there are still some limitations such as short-half life, rapid clearance, and safety concerns [72]. Therefore developing an effective delivery system and combining them with stem cells are required. Nanobiomaterials have been used to convey growth factors in DO before [229], since they can achieve more effective and controlled release of the growth factors. Moreover, they can add strength to the mechanical properties of scaffolds and provide an environment that resembles the extracellular matrix of bone hence, promoting ASCs proliferation and differentiation into osteoblasts. Therefore, choosing the right nanocomposite scaffold is essential for the successful differentiation and proliferation of ASCs in DO. Further research is then needed to answer all these questions including when to inject stem cells in DO and when to inject nanocomposite scaffolds and which material is optimal in inducing osteogenic differentiation in DO? Which growth factor and delivery system are the optimal one to be used with stem cells for osteogenic induction? All these questions should be addressed in order to optimize the use of ASCs in bone regeneration and DO. Well-designed preclinical and 
translational studies to establish the safe and efficacious use of cell-therapies to enhance bone regeneration are needed.

\section{Conflict of Interests}

The authors declare that there is no conflict of interests regarding the publication of this paper.

\section{References}

[1] P. S. Pipitone and S. Rehman, "Management of traumatic bone loss in the lower extremity," Orthopedic Clinics of North America, vol. 45, no. 4, pp. 469-482, 2014.

[2] F. Rauch and F. H. Glorieux, "Osteogenesis imperfecta," The Lancet, vol. 363, no. 9418, pp. 1377-1385, 2004.

[3] O. Ashman and A. M. Phillips, "Treatment of non-unions with bone defects: which option and why?" Injury, vol. 44, supplement 1, pp. S43-S45, 2013.

[4] H. Tsuchiya, "Treatment of segmental bone loss due to tumors," in Management of Limb-Length Discrepancies, R. H. A. J. J. McCarthy, Ed., pp. 173-178, American Academy of Orthopaedic Surgeons, Rosemont, Ill, USA, 2011.

[5] Z. S. Al-Aql, A. S. Alagl, D. T. Graves, L. C. Gerstenfeld, and T. A. Einhorn, "Molecular mechanisms controlling bone formation during fracture healing and distraction osteogenesis," Journal of Dental Research, vol. 87, no. 2, pp. 107-118, 2008.

[6] C. Papakostidis, M. Bhandari, and P. V. Giannoudis, "Distraction osteogenesis in the treatment of long bone defects of the lower limbs: effectiveness, complications and clinical results; a systematic review and meta-analysis," Bone and Joint Journal, vol. 95, no. 12, pp. 1673-1680, 2013.

[7] A. Nauth, M. D. McKee, T. A. Einhorn, J. T. Watson, R. Li, and E. H. Schemitsch, "Managing bone defects," Journal of Orthopaedic Trauma, vol. 25, no. 8, pp. 462-466, 2011.

[8] R. Dimitriou, E. Jones, D. McGonagle, and P. V. Giannoudis, "Bone regeneration: current concepts and future directions," BMC Medicine, vol. 9, article 66, 2011.

[9] K. N. Malizos, C. G. Zalavras, P. N. Soucacos, A. E. Beris, and J. R. Urbaniak, "Free vascularized fibular grafts for reconstruction of skeletal defects," The Journal of the American Academy of Orthopaedic Surgeons, vol. 12, no. 5, pp. 360-369, 2004.

[10] A. Codivilla, "On the means of lengthening, in the lower limbs, the muscles and tissues which are shortened through deformity," The Journal of Bone \& Joint Surgery, vol. 2, no. 4, pp. 353-369, 1905.

[11] G. A. Ilizarov, "The tension-stress effect on the genesis and growth of tissues. Part I. The influence of stability of fixation and soft-tissue preservation," Clinical Orthopaedics and Related Research, no. 238, pp. 249-281, 1989.

[12] A. A. Green, "The Ilizarov method of distraction osteogenesis," in Management of Limb Length Discrepancies, R. C. Hamdy and J. J. McCarthy, Eds., pp. 39-44, American Academy of Orthopaedic Surgeons, Rosemont, Ill, USA, 2011.

[13] G. A. Ilizarov, "Clinical application of the tension-stress effect for limb lengthening," Clinical Orthopaedics and Related Research, no. 250, pp. 8-26, 1990.

[14] R. C. Hamdy, J. S. Rendon, and M. Tabrizian, "Distraction osteogenesis and its challenges in bone regeneration," in Bone Regeneration, chapter 8, InTech, Rijeka, Croatia, 2012.

[15] J. G. Birch and M. L. Samchukov, "Use of the Ilizarov method to correct lower limb deformities in children and adolescents,"
Journal of the American Academy of Orthopaedic Surgeons, vol. 12, no. 3, pp. 144-154, 2004.

[16] G. A. Ilizarov, "The tension-stress effect on the genesis and growth of tissues: part II. The influence of the rate and frequency of distraction," Clinical Orthopaedics and Related Research, no. 239, pp. 263-285, 1989.

[17] R. Y. Goldstein, C. J. Jordan, T. M. Mclaurin, and A. Grant, "The evolution of the ilizarov technique: part 2: the principles of distraction osteosynthesis," Bulletin of the Hospital for Joint Disease, vol. 71, no. 1, pp. 96-103, 2013.

[18] J. H. Murray and R. D. Fitch, "Distraction histiogenesis: principles and indications," Journal of the American Academy of Orthopaedic Surgeons, vol. 4, no. 6, pp. 317-327, 1996.

[19] B. Fink, C. Pollnau, M. Vogel, R. Skripitz, and A. Enderle, "Histomorphometry of distraction osteogenesis during experimental tibial lengthening," Journal of Orthopaedic Trauma, vol. 17, no. 2, pp. 113-118, 2003.

[20] J. Aronson, B. Good, C. Stewart, B. Harrison, and J. Harp, "Preliminary studies of mineralization during distraction osteogenesis," Clinical Orthopaedics and Related Research, no. 250, pp. 43-49, 1990.

[21] I. H. Choi, C. Y. Chung, T.-J. Cho, and W. J. Yoo, "Angiogenesis and mineralization during distraction osteogenesis," Journal of Korean Medical Science, vol. 17, no. 4, pp. 435-447, 2002.

[22] N. Yasui, M. Sato, T. Ochi et al., "Three modes of ossification during distraction osteogenesis in the rat," Journal of Bone and Joint Surgery B, vol. 79, no. 5, pp. 824-830, 1997.

[23] R. C. Hamdy, A. Silvestri, C. H. Rivard, and M. Ehrlich, "Histologic evaluation of bone regeneration in cases of limb lengthening by Ilizarov's technique. An experimental study in the dog," Annales de Chirurgie, vol. 51, no. 8, pp. 875-883, 1997.

[24] R. C. Hamdy, M. Amako, L. Beckman et al., "Effects of osteogenic protein-1 on distraction osteogenesis in rabbits," Bone, vol. 33, no. 2, pp. 248-255, 2003.

[25] M. Sato, N. Yasui, T. Nakase et al., "Expression of bone matrix proteins mRNA during distraction osteogenesis," Journal of Bone and Mineral Research, vol. 13, no. 8, pp. 1221-1231, 1998.

[26] L. C. Gerstenfeld, D. M. Cullinane, G. L. Barnes, D. T. Graves, and T. A. Einhorn, "Fracture healing as a post-natal developmental process: molecular, spatial, and temporal aspects of its regulation," Journal of Cellular Biochemistry, vol. 88, no. 5, pp. 873-884, 2003.

[27] J. Aronson, B. H. Harrison, C. L. Stewart, and J. H. Harp Jr., "The histology of distraction osteogenesis using different external fixators," Clinical Orthopaedics and Related Research, no. 241, pp. 106-116, 1989.

[28] J. Aronson, X. C. Shen, R. A. Skinner, W. R. Hogue, T. M. Badger, and J. Lumpkin C.K., "Rat model of distraction osteogenesis," Journal of Orthopaedic Research, vol. 15, no. 2, pp. 221-226, 1997.

[29] M. Makarov, J. Birch, and M. Samchukov, "The role of variable muscle adaptation to limb lengthening in the development of joint contractures: an experimental study in the goat," Journal of Pediatric Orthopaedics, vol. 29, no. 2, pp. 175-181, 2009.

[30] D. Y. Lee, T.-J. Cho, J. A. Kim et al., "Mobilization of endothelial progenitor cells in fracture healing and distraction osteogenesis," Bone, vol. 42, no. 5, pp. 932-941, 2008.

[31] I. H. Choi, J. H. Ahn, C. Y. Chung, and T.-J. Cho, "Vascular proliferation and blood supply during distraction osteogenesis: a scanning electron microscopic observation," Journal of Orthopaedic Research, vol. 18, no. 5, pp. 698-705, 2000. 
[32] D. M. Pacicca, N. Patel, C. Lee et al., "Expression of angiogenic factors during distraction osteogenesis," Bone, vol. 33, no. 6, pp. 889-898, 2003.

[33] F. Rauch, D. Lauzier, S. Croteau, R. Travers, F. H. Glorieux, and R. Hamdy, "Temporal and spatial expression of bone morphogenetic protein- $2,-4$, and -7 during distraction osteogenesis in rabbits," Bone, vol. 27, no. 3, pp. 453-459, 2000.

[34] T. Haque, M. Amako, S. Nakada, D. Lauzier, and R. C. Hamdy, "An immunohistochemical analysis of the temporal and spatial expression of growth factors FGF 1, 2 and 18, IGF 1 and 2, and TGFbetal during distraction osteogenesis," Histology and Histopathology, vol. 22, no. 2, pp. 119-128, 2007.

[35] T. Haque, F. Hamade, N. Alam et al., "Characterizing the BMP pathway in a wild type mouse model of distraction osteogenesis," Bone, vol. 42, no. 6, pp. 1144-1153, 2008.

[36] T. Haque, M. Mandu-Hrit, F. Rauch, D. Lauzier, M. Tabrizian, and R. C. Hamdy, "Immunohistochemical localization of bone morphogenetic protein-signaling Smads during long-bone distraction osteogenesis," Journal of Histochemistry and Cytochemistry, vol. 54, no. 4, pp. 407-415, 2006.

[37] C. Huang and R. Ogawa, "Mechanotransduction in bone repair and regeneration," The FASEB Journal, vol. 24, no. 10, pp. 3625$3632,2010$.

[38] S. Weiss, R. Baumgart, M. Jochum, C. J. Strasburger, and M. Bidlingmaier, "Systemic regulation of distraction osteogenesis: a cascade of biochemical factors," Journal of Bone and Mineral Research, vol. 17, no. 7, pp. 1280-1289, 2002.

[39] Z. S. Haidar, M. Tabrizian, and R. C. Hamdy, "A hybrid rhOP-1 delivery system enhances new bone regeneration and consolidation in a rabbit model of distraction osteogenesis," Growth Factors, vol. 28, no. 1, pp. 44-55, 2010.

[40] Z. S. Haidar, R. C. Hamdy, and M. Tabrizian, "Delivery of recombinant bone morphogenetic proteins for bone regeneration and repair. Part A: current challenges in BMP delivery," Biotechnology Letters, vol. 31, no. 12, pp. 1817-1824, 2009.

[41] Z. S. Haidar, F. Azari, R. C. Hamdy, and M. Tabrizian, "Modulated release of OP-1 and enhanced preosteoblast differentiation using a core-shell nanoparticulate system," Journal of Biomedical Materials Research Part A, vol. 91, no. 3, pp. 919-928, 2009.

[42] B. Dohin, N. Dahan-Oliel, F. Fassier, and R. Hamdy, "Enhancement of difficult nonunion in children with osteogenic protein1 (OP-1): early experience," Clinical Orthopaedics and Related Research, vol. 467, no. 12, pp. 3230-3238, 2009.

[43] M. Mandu-Hrit, E. Seifert, M. Kotsiopriftis et al., "OP-1 injection increases VEGF expression but not angiogenesis in a rabbit model of distraction osteogenesis," Growth Factors, vol. 26, no. 3, pp. 143-151, 2008.

[44] K. Zakhary, D. Motakis, R. H. Hamdy, P. Campisi, Y. Amar, and M.-L. Lessard, "Effect of recombinant human bone morphogenetic protein 7 on bone density during distraction osteogenesis of the rabbit mandible," Journal of Otolaryngology, vol. 34, no. 6, pp. 407-414, 2005.

[45] P. Campisi, R. C. Hamdy, D. Lauzier, M. Amako, F. Rauch, and M. L. Lessard, "Expression of bone morphogenetic proteins during mandibular distraction osteogenesis," Plastic and Reconstructive Surgery, vol. 111, no. 1, pp. 201-210, 2003.

[46] B. Kasaai, P. Moffatt, L. Al-Salmi, D. Lauzier, L. Lessard, and R. C. Hamdy, "Spatial and temporal localization of WNT signaling proteins in a mouse model of distraction osteogenesis," Journal of Histochemistry and Cytochemistry, vol. 60, no. 3, pp. 219-228, 2012.
[47] O. Holbein, C. Neidlinger-Wilke, G. Suger, L. Kinzl, and L. Claes, "Ilizarov callus distraction produces systemic bone cell mitogens," Journal of Orthopaedic Research, vol. 13, no. 4, pp. 629-638, 1995.

[48] P. Campisi, R. C. Hamdy, D. Lauzier, M. Amako, M. D. Schloss, and M. L. Lessard, "Overview of the radiology, histology, and bone morphogenetic protein expression during distraction osteogenesis of the mandible," Journal of Otolaryngology, vol. 31, no. 5, pp. 281-286, 2002.

[49] M. Mandu-Hrit, T. Haque, D. Lauzier et al., "Early injection of OP-1 during distraction osteogenesis accelerates new bone formation in rabbits," Growth Factors, vol. 24, no. 3, pp. 172-183, 2006.

[50] N. Alam, R. St-Arnaud, D. Lauzier, V. Rosen, and R. C. Hamdy, "Are endogenous BMPs necessary for bone healing during distraction osteogenesis?" Clinical Orthopaedics and Related Research, vol. 467, no. 12, pp. 3190-3198, 2009.

[51] V. D. Polyzois, I. P. Stathopoulos, K. Lampropoulou-Adamidou, E. S. Vasiliadis, J. Vlamis, and S. G. Pneumaticos, "Strategies for managing bone defects of the lower extremity," Clinics in Podiatric Medicine and Surgery, vol. 31, no. 4, pp. 577-584, 2014.

[52] J. J. Keeling, J. R. Hsu, S. B. Shawen, and R. C. Andersen, "Strategies for managing massive defects of the foot in highenergy combat injuries of the lower extremity," Foot and Ankle Clinics, vol. 15, no. 1, pp. 139-149, 2010.

[53] D. S. Feldman and S. Chaudhry, "Distraction osteogenesis: lengthening with external fixators," in Management of LimbLength Discrepancies, American Academy of Orthopaedic Surgeons, Rosemont, Ill, USA, 2011.

[54] R. J. Velazquez, D. F. Bell, P. F. Armstrong, P. Babyn, and R. Tibshirani, "Complications of use of the Ilizarov technique in the correction of limb deformities in children," The Journal of Bone \& Joint Surgery - American Volume, vol. 75, no. 8, pp. 11481156, 1993.

[55] D. Paley, "Problems, obstacles, and complications of limb lengthening by the Ilizarov technique," Clinical Orthopaedics and Related Research, no. 250, pp. 81-104, 1990.

[56] E. García-Cimbrelo, B. Olsen, M. Ruiz-Yagüe, N. FernandezBaíllo, and L. Munuera-Martínez, "Ilizarov technique. Results and difficulties," Clinical Orthopaedics and Related Research, no. 283, pp. 116-123, 1992.

[57] L. Claes, P. Augat, S. Schorlemmer, C. Konrads, A. Ignatius, and C. Ehrnthaller, "Temporary distraction and compression of a diaphyseal osteotomy accelerates bone healing," Journal of Orthopaedic Research, vol. 26, no. 6, pp. 772-777, 2008.

[58] S. Mori, M. Akagi, A. Kikuyama, Y. Yasuda, and C. Hamanishi, "Axial shortening during distraction osteogenesis leads to enhanced bone formation in a rabbit model through the HIF-1 $\alpha$ /vascular endothelial growth factor system," Journal of Orthopaedic Research, vol. 24, no. 4, pp. 653-663, 2006.

[59] W. W. Hou, Z. L. Zhu, Y. Zhou, C. X. Zhang, and H. Y. $\mathrm{Yu}$, "Involvement of Wnt activation in the micromechanical vibration-enhanced osteogenic response of osteoblasts," Journal of Orthopaedic Science, vol. 16, no. 5, pp. 598-605, 2011.

[60] T. Hagiwara and W. H. Bell, "Effect of electrical stimulation on mandibular distraction osteogenesis," Journal of CranioMaxillofacial Surgery, vol. 28, no. 1, pp. 12-19, 2000.

[61] K. Kawamoto, W.-C. Kim, Y. Tsuchida et al., "Effects of alternating current electrical stimulation on lengthening callus," Journal of Pediatric Orthopaedics Part B, vol. 14, no. 4, pp. 299-302, 2005. 
[62] K. Narasaki, H. Shimizu, M. Beppu, H. Aoki, M. Takagi, and M. Takashi, "Effect of extracorporeal shock waves on callus formation during bone lengthening," Journal of Orthopaedic Science, vol. 8, no. 4, pp. 474-481, 2003.

[63] J.-P. Lai, F.-S. Wang, C.-M. Hung, C.-J. Wang, C.-J. Huang, and Y.-R. Kuo, "Extracorporeal shock wave accelerates consolidation in distraction osteogenesis of the rat mandible," Journal of Trauma-Injury, Infection and Critical Care, vol. 69, no. 5, pp. 1252-1258, 2010.

[64] A. Shimazaki, K. Inui, Y. Azuma, N. Nishimura, and Y. Yamano, "Low-intensity pulsed ultrasound accelerates bone maturation in distraction osteogenesis in rabbits," Journal of Bone and Joint Surgery: Series B, vol. 82, no. 7, pp. 1077-1082, 2000.

[65] L. Claes and B. Willie, "The enhancement of bone regeneration by ultrasound," Progress in Biophysics and Molecular Biology, vol. 93, no. 1-3, pp. 384-398, 2007.

[66] J. W. Busse, J. Kaur, B. Mollon et al., "Low intensity pulsed ultrasonography for fractures: systematic review of randomised controlled trials," British Medical Journal, vol. 338, article b351, 2009.

[67] A. M. Makhdom, F. Rauch, D. Lauzier, and R. C. Hamdy, "The effect of systemic administration of sclerostin antibody in a mouse model of distraction osteogenesis," Journal of Musculoskeletal Neuronal Interactions, vol. 14, no. 1, pp. 124-130, 2014.

[68] C. Sen, T. Gunes, M. Erdem, R. D. Koseoglu, and N. O. Filiz, "Effects of calcitonin and alendronate on distraction osteogenesis," International Orthopaedics, vol. 30, no. 4, pp. 272277, 2006.

[69] A. Abbaspour, M. Takahashi, K. Sairyo et al., "Optimal increase in bone mass by continuous local infusion of alendronate during distraction osteogenesis in rabbits," Bone, vol. 44, no. 5, pp. 917-923, 2009.

[70] P. Kiely, K. Ward, C. M. Bellemore, J. Briody, C. T. Cowell, and D. G. Little, "Bisphosphonate rescue in distraction osteogenesis: a case series," Journal of Pediatric Orthopaedics, vol. 27, no. 4, pp. 467-471, 2007.

[71] K. Yamane, T. Okano, H. Kishimoto, and H. Hagino, "Effect of ED-71 on modeling of bone in distraction osteogenesis," Bone, vol. 24, no. 3, pp. 187-193, 1999.

[72] A. M. Makhdom and R. C. Hamdy, "The role of growth factors on acceleration of bone regeneration during distraction osteogenesis," Tissue Engineering-Part B: Reviews, vol. 19, no. 5, pp. 442-453, 2013.

[73] B. C. Cho, J. H. Moon, H. Y. Chung, J. W. Park, I. C. Kweon, and I. S. Kim, "The bone regenerative effect of growth hormone on consolidation in mandibular distraction osteogenesis of a dog model," The Journal of Craniofacial Surgery, vol. 14, no. 3, pp. 417-425, 2003.

[74] S. N. Lissenberg-Thunnissen, D. J. J. de Gorter, C. F. M. Sier, and I. B. Schipper, "Use and efficacy of bone morphogenetic proteins in fracture healing," International Orthopaedics, vol. 35, no. 9, pp. 1271-1280, 2011.

[75] Z. S. Haidar, R. C. Hamdy, and M. Tabrizian, "Delivery of recombinant bone morphogenetic proteins for bone regeneration and repair. Part B. Delivery systems for BMPs in orthopaedic and craniofacial tissue engineering," Biotechnology Letters, vol. 31, no. 12, pp. 1825-1835, 2009.

[76] Z. S. Haidar, R. C. Hamdy, and M. Tabrizian, "Biocompatibility and safety of a hybrid core-shell nanoparticulate OP-1 delivery system intramuscularly administered in rats," Biomaterials, vol. 31, no. 10, pp. 2746-2754, 2010.
[77] Z. S. Haidar, R. C. Hamdy, and M. Tabrizian, "Protein release kinetics for core-shell hybrid nanoparticles based on the layerby-layer assembly of alginate and chitosan on liposomes," Biomaterials, vol. 29, no. 9, pp. 1207-1215, 2008.

[78] H. I. Canter, I. Vargel, and M. E. Mavili, "Reconstruction of mandibular defects using autografts combined with demineralized bone matrix and cancellous allograft," Journal of Craniofacial Surgery, vol. 18, no. 1, pp. 95-103, 2007.

[79] I. Hatzokos, S. I. Stavridis, E. Iosifidou, D. Karataglis, and A. Christodoulou, "Autologous bone marrow grafting combined with demineralized bone matrix improves consolidation of docking site after distraction osteogenesis," The Journal of Bone \& Joint Surgery-American Volume, vol. 93, no. 7, pp. 671-678, 2011.

[80] M. K. Sen and T. Miclau, "Autologous iliac crest bone graft: should it still be the gold standard for treating nonunions?" Injury, vol. 38, no. 1, pp. S75-S80, 2007.

[81] A. J. Weiland, "Current concepts review. Vascularized free bone transplants," Journal of Bone and Joint Surgery A, vol. 63, no. 1, pp. 166-169, 1981.

[82] M. B. Wood, "Free vascularized fibular grafting-25 years' experience: tips, techniques, and pearls," Orthopedic Clinics of North America, vol. 38, no. 1, pp. 1-12, 2007.

[83] T. W. Bauer and G. F. Muschler, "Bone graft materials: an overview of the basic science," Clinical Orthopaedics and Related Research, no. 371, pp. 10-27, 2000.

[84] E. Ahlmann, M. Patzakis, N. Roidis, L. Shepherd, and P. Holtom, "Comparison of anterior and posterior iliac crest bone grafts in terms of harvest-site morbidity and functional outcomes," The Journal of Bone \& Joint Surgery-American Volume, vol. 84, no. 5, pp. 716-720, 2002.

[85] E. M. Younger and M. W. Chapman, "Morbidity at bone graft donor sites," Journal of Orthopaedic Trauma, vol. 3, no. 3, pp. 192-195, 1989.

[86] J. A. Goulet, L. E. Senunas, G. L. DeSilva, and M. L. V. H. Greenfield, "Autogenous iliac crest bone graft: complications and functional assessment," Clinical Orthopaedics and Related Research, no. 339, pp. 76-81, 1997.

[87] J. T. Newman, P. F. Stahel, W. R. Smith, G. V. Resende, D. J. Hak, and S. J. Morgan, "A new minimally invasive technique for large volume bone graft harvest for treatment of fracture nonunions," Orthopedics, vol. 31, no. 3, pp. 257-261, 2008.

[88] F. M. Kovar and G. E. Wozasek, "Bone graft harvesting using the RIA (reaming irrigation aspirator) system - a quantitative assessment," Wiener Klinische Wochenschrift, vol. 123, no. 9-10, pp. 285-290, 2011.

[89] N. K. Kanakaris, D. Morell, S. Gudipati, S. Britten, and P. V. Giannoudis, "Reaming irrigator aspirator system: early experience of its multipurpose use," Injury, vol. 42, supplement 4, pp. S28-S34, 2011.

[90] H. C. Sagi, M. L. Young, L. Gerstenfeld, T. A. Einhorn, and P. Tornetta, "Qualitative and quantitative differences between bone graft obtained from the medullary canal (with a reamer/irrigator/aspirator) and the iliac crest of the same patient," Journal of Bone and Joint Surgery: Series A, vol. 94, no. 23, pp. 2128-2135, 2012.

[91] C. G. Finkemeier, "Bone-grafting and bone-graft substitutes," The Journal of Bone \& Joint Surgery -American Volume, vol. 84, no. 3, pp. 454-464, 2002.

[92] M. Strioga, S. Viswanathan, A. Darinskas, O. Slaby, and J. Michalek, "Same or not the same? comparison of adipose tissuederived versus bone marrow-derived mesenchymal stem and 
stromal cells," Stem Cells and Development, vol. 21, no. 14, pp. 2724-2752, 2012.

[93] A. I. Caplan, "The mesengenic process," Clinics in Plastic Surgery, vol. 21, no. 3, pp. 429-435, 1994.

[94] P. A. Zuk, M. Zhu, H. Mizuno et al., "Multilineage cells from human adipose tissue: implications for cell-based therapies," Tissue Engineering, vol. 7, no. 2, pp. 211-228, 2001.

[95] P. A. Zuk, M. Zhu, P. Ashjian et al., "Human adipose tissue is a source of multipotent stem cells," Molecular Biology of the Cell, vol. 13, no. 12, pp. 4279-4295, 2002.

[96] P. Lichte, H. C. Pape, T. Pufe, P. Kobbe, and H. Fischer, "Scaffolds for bone healing: concepts, materials and evidence," Injury, vol. 42, no. 6, pp. 569-573, 2011.

[97] F. Matassi, L. Nistri, D. C. Paez, and M. Innocenti, "New biomaterials for bone regeneration," Clinical Cases in Mineral and Bone Metabolism, vol. 8, no. 1, pp. 21-24, 2011.

[98] S. J. Seo, C. Mahapatra, R. K. Singh, J. Knowles, and H. Kim, "Strategies for osteochondral repair: focus on scaffolds," Journal of Tissue Engineering, vol. 5, pp. 1-14, 2014.

[99] X. Li, L. Wang, Y. Fan, Q. Feng, F. Z. Cui, and F. Watari, "Nanostructured scaffolds for bone tissue engineering," Journal of Biomedical Materials Research Part A, vol. 101, no. 8, pp. 24242435, 2013.

[100] L. Zhang, F. X. Gu, J. M. Chan, A. Z. Wang, R. S. Langer, and O. C. Farokhzad, "Nanoparticles in medicine: therapeutic applications and developments," Clinical Pharmacology \& Therapeutics, vol. 83, no. 5, pp. 761-769, 2008.

[101] W.-J. Li, R. Tuli, X. Huang, P. Laquerriere, and R. S. Tuan, "Multilineage differentiation of human mesenchymal stem cells in a three-dimensional nanofibrous scaffold," Biomaterials, vol. 26, no. 25, pp. 5158-5166, 2005.

[102] Y. Khan, M. J. Yaszemski, A. G. Mikos, and C. T. Laurencin, "Tissue engineering of bone: material and matrix considerations," The Journal of Bone \& Joint Surgery-American Volume, vol. 90, supplement 1, pp. 36-42, 2008.

[103] K. Tuzlakoglu, N. Bolgen, A. J. Salgado, M. E. Gomes, E. Piskin, and R. L. Reis, "Nano- and micro-fiber combined scaffolds: a new architecture for bone tissue engineering," Journal of Materials Science: Materials in Medicine, vol. 16, no. 12, pp. 10991104, 2005.

[104] A. Tautzenberger, A. Kovtun, and A. Ignatius, "Nanoparticles and their potential for application in bone," International Journal of Nanomedicine, vol. 7, pp. 4545-4557, 2012.

[105] K. M. Woo, J.-H. Jun, V. J. Chen et al., "Nano-fibrous scaffolding promotes osteoblast differentiation and biomineralization," Biomaterials, vol. 28, no. 2, pp. 335-343, 2007.

[106] A. S. Posner, “The mineral of bone," Clinical Orthopaedics and Related Research, vol. 200, pp. 87-99, 1985.

[107] S. Weiner, W. Traub, and H. D. Wagner, "Lamellar bone: structure-function relations," Journal of Structural Biology, vol. 126, no. 3, pp. 241-255, 1999.

[108] C. Hellmich and F. Ulm, "Average hydroxyapatite concentration is uniform in the extracollagenous ultrastructure of mineralized tissues: evidence at the 1-10- $\mu \mathrm{m}$ scale," Biomechanics and Modeling in Mechanobiology, vol. 2, no. 1, pp. 21-36, 2003.

[109] C. Rey, H.-M. Kim, L. Gerstenfeld, and M. J. Glimcher, "Structural and chemical characteristics and maturation of the calcium-phosphate crystals formed during the calcification of the organic matrix synthesized by chicken osteoblasts in cell culture," Journal of Bone and Mineral Research, vol. 10, no. 10, pp. 1577-1588, 1995.
[110] B. R. Olsen, "Morphogenesis: collagen it takes and bone it makes," Current Biology, vol. 6, no. 6, pp. 645-647, 1996.

[111] M. F. Young, J. M. Kerr, K. Ibaraki, A.-M. Heegaard, and P. G. Robey, "Structure, expression, and regulation of the major noncollagenous matrix proteins of bone," Clinical Orthopaedics and Related Research, no. 281, pp. 275-294, 1992.

[112] Z. Lu, S.-I. Roohani-Esfahani, G. Wang, and H. Zreiqat, "Bone biomimetic microenvironment induces osteogenic differentiation of adipose tissue-derived mesenchymal stem cells," Nanomedicine, vol. 8, no. 4, pp. 507-515, 2012.

[113] F. M. Ghorbani, B. Kaffashi, P. Shokrollahi, E. Seyedjafari, and A. Ardeshirylajimi, "PCL/chitosan/Zn-doped nHA electrospun nanocomposite scaffold promotes adipose derived stem cells adhesion and proliferation," Carbohydrate Polymers, vol. 118, pp. 133-142, 2015.

[114] S. D. McCullen, Y. Zhu, S. H. Bernacki et al., "Electrospun composite poly(L-lactic acid)/tricalcium phosphate scaffolds induce proliferation and osteogenic differentiation of human adipose-derived stem cells," Biomedical Materials, vol. 4, no. 3, Article ID 035002, 2009.

[115] S. Kim, K. Ahn, M. S. Park, J. Lee, C. Y. Choi, and B. Kim, "A poly(lactide-co-glycolide)/hydroxyapatite composite scaffold with enhanced osteoconductivity," Journal of Biomedical Materials Research-Part A, vol. 80, no. 1, pp. 206-215, 2007.

[116] E. Gazzerro and E. Canalis, "Bone morphogenetic proteins and their antagonists," Reviews in Endocrine and Metabolic Disorders, vol. 7, no. 1-2, pp. 51-65, 2006.

[117] K. Miyazono, Y. Kamiya, and M. Morikawa, "Bone morphogenetic protein receptors and signal transduction," The Journal of Biochemistry, vol. 147, no. 1, pp. 35-51, 2010.

[118] S. Ebara and K. Nakayama, "Mechanism for the action of bone morphogenetic proteins and regulation of their activity," Spine, vol. 27, no. 16, supplement 1, pp. S10-S15, 2002.

[119] I. L. Weissman, "Translating stem and progenitor cell biology to the clinic: barriers and opportunities," Science, vol. 287, no. 5457, pp. 1442-1446, 2000.

[120] M. J. Shamblott, J. Axelman, S. Wang et al., "Derivation of pluripotent stem cells from cultured human primordial germ cells," Proceedings of the National Academy of Sciences of the United States of America, vol. 95, no. 23, pp. 13726-13731, 1998.

[121] A. M. Poulsom R, S. J. Forbes, and N. A. Wright, "Adult stem cell plasticity," The Journal of Pathology, vol. 197, pp. 441-456, 2002.

[122] J. Itskovitz-Eldor, M. Schuldiner, D. Karsenti et al., "Differentiation of human embryonic stem cells into embryoid bodies compromising the three embryonic germ layers," Molecular Medicine, vol. 6, no. 2, pp. 88-95, 2000.

[123] B. C. Heng, T. Cao, H. K. Haider, D. Z. M. Wang, E. K.-W. Sim, and S. C. Ng, "An overview and synopsis of techniques for directing stem cell differentiation in vitro," Cell and Tissue Research, vol. 315, no. 3, pp. 291-303, 2004.

[124] C. M. Verfaillie, "Adult stem cells: assessing the case for pluripotency," Trends in Cell Biology, vol. 12, no. 11, pp. 502-508, 2002.

[125] M. F. Pittenger, A. M. Mackay, S. C. Beck et al., "Multilineage potential of adult human mesenchymal stem cells," Science, vol. 284, no. 5411, pp. 143-147, 1999.

[126] V. Feisst, A. E. S. Brooks, C.-J. J. Chen, and P. R. Dunbar, "Characterization of mesenchymal progenitor cell populations directly derived from human dermis," Stem Cells and Development, vol. 23, no. 6, pp. 631-642, 2014. 
[127] J. G. Toma, M. Akhavan, K. J. L. Fernandes et al., "Isolation of multipotent adult stem cells from the dermis of mammalian skin," Nature Cell Biology, vol. 3, no. 9, pp. 778-784, 2001.

[128] I. Rogers and R. F. Casper, "Umbilical cord blood stem cells," Best Practice and Research: Clinical Obstetrics and Gynaecology, vol. 18, no. 6, pp. 893-908, 2004.

[129] S. Kern, H. Eichler, J. Stoeve, H. Klüter, and K. Bieback, "Comparative analysis of mesenchymal stem cells from bone marrow, umbilical cord blood, or adipose tissue," Stem Cells, vol. 24, no. 5, pp. 1294-1301, 2006.

[130] M. Dominici, K. Le Blanc, I. Mueller et al., "Minimal criteria for defining multipotent mesenchymal stromal cells. The International Society for Cellular Therapy position statement," Cytotherapy, vol. 8, no. 4, pp. 315-317, 2006.

[131] K. Le Blanc, L. Tammik, B. Sundberg, S. E. Haynesworth, and O. Ringdén, "Mesenchymal stem cells inhibit and stimulate mixed lymphocyte cultures and mitogenic responses independently of the major histocompatibility complex," Scandinavian Journal of Immunology, vol. 57, no. 1, pp. 11-20, 2003.

[132] G. Siegel, R. Schäfer, and F. Dazzi, "The immunosuppressive properties of mesenchymal stem cells," Transplantation, vol. 87, no. 9, pp. S45-49, 2009.

[133] T. Yi and S. U. Song, "Immunomodulatory properties of mesenchymal stem cells and their therapeutic applications," Archives of Pharmacal Research, vol. 35, no. 2, pp. 213-221, 2012.

[134] C. K. Rebelatto, A. M. Aguiar, M. P. Moretão et al., "Dissimilar differentiation of mesenchymal stem cells from bone marrow, umbilical cord blood, and adipose tissue," Experimental Biology and Medicine, vol. 233, no. 7, pp. 901-913, 2008.

[135] F. P. Barry and J. M. Murphy, "Mesenchymal stem cells: clinical applications and biological characterization," International Journal of Biochemistry and Cell Biology, vol. 36, no. 4, pp. 568-584, 2004.

[136] M. B. Murphy, K. Moncivais, and A. I. Caplan, "Mesenchymal stem cells: environmentally responsive therapeutics for regenerative medicine," Experimental \& Molecular Medicine, vol. 45, no. 11, article e54, 2013.

[137] A. J. Friedenstein, R. K. Chailakhjan, and K. S. Lalykina, "The development of fibroblast colonies in monolayer cultures of guinea-pig bone marrow and spleen cells," Cell and Tissue Kinetics, vol. 3, no. 4, pp. 393-403, 1970.

[138] J. M. Seong, B.-C. Kim, J.-H. Park, I. K. Kwon, A. Mantalaris, and Y.-S. Hwang, "Stem cells in bone tissue engineering," Biomedical Materials, vol. 5, no. 6, Article ID 062001, 2001.

[139] R. L. R. Van, C. E. Bayliss, and D. A. K. Roncari, "Cytological and enzymological characterization of adult human adipocyte precursors in culture," The Journal of Clinical Investigation, vol. 58, no. 3, pp. 699-704, 1976.

[140] H. Mizuno, "Adipose-derived stem cells for tissue repair and regeneration: ten years of research and a literature review," Journal of Nippon Medical School, vol. 76, no. 2, pp. 56-66, 2009.

[141] L. Aust, B. Devlin, S. J. Foster et al., "Yield of human adiposederived adult stem cells from liposuction aspirates," Cytother$a p y$, vol. 6, no. 1, pp. 7-14, 2004.

[142] P. C. Baer and H. Geiger, "Adipose-derived mesenchymal stromal/stem cells: tissue localization, characterization, and heterogeneity," Stem Cells International, vol. 2012, Article ID 812693, 11 pages, 2012.

[143] C. T. Gomillion and K. J. L. Burg, "Stem cells and adipose tissue engineering," Biomaterials, vol. 27, no. 36, pp. 6052-6063, 2006.
[144] J. M. Gimble and F. Guilak, "Adipose-derived adult stem cells: isolation, characterization, and differentiation potential," Cytotherapy, vol. 5, no. 5, pp. 362-369, 2003.

[145] F. Mosna, L. Sensebé, and M. Krampera, "Human bone marrow and adipose tissue mesenchymal stem cells: a user's guide," Stem Cells and Development, vol. 19, no. 10, pp. 1449-1470, 2010.

[146] C. Brayfield, K. Marra, and J. P. Rubin, "Adipose stem cells for soft tissue regeneration," Handchirurgie, Mikrochirurgie, Plastische Chirurgie, vol. 42, no. 2, pp. 124-128, 2010.

[147] J. M. Gimble and F. Guilak, "Differentiation potential of adipose derived adult stem (ADAS) cells," Current Topics in Developmental Biology, vol. 58, pp. 137-160, 2003.

[148] B. Lindroos, R. Suuronen, and S. Miettinen, "The potential of adipose stem cells in regenerative medicine," Stem Cell Reviews and Reports, vol. 7, no. 2, pp. 269-291, 2011.

[149] B. A. Bunnell, M. Flaat, C. Gagliardi, B. Patel, and C. Ripoll, "Adipose-derived stem cells: isolation, expansion and differentiation," Methods, vol. 45, no. 2, pp. 115-120, 2008.

[150] A. C. Boquest, A. Shahdadfar, J. E. Brinchmann, and P. Collas, "Isolation of stromal stem cells from human adipose tissue," Methods in Molecular Biology, vol. 325, pp. 35-46, 2006.

[151] K. Gonda, T. Shigeura, T. Sato et al., "Preserved proliferative capacity and multipotency of human adipose-derived stem cells after long-term cryopreservation," Plastic and Reconstructive Surgery, vol. 121, no. 2, pp. 401-410, 2008.

[152] H. Li, L. Zimmerlin, K. G. Marra, V. S. Donnenberg, A. D. Donnenberg, and J. P. Rubin, "Adipogenic potential of adipose stem cell subpopulations," Plastic and Reconstructive Surgery, vol. 128, no. 3, pp. 663-672, 2011.

[153] J. B. Mitchell, K. McIntosh, S. Zvonic et al., "Immunophenotype of human adipose-derived cells: temporal changes in stromalassociated and stem cell-associated markers," Stem Cells, vol. 24, no. 2, pp. 376-385, 2006.

[154] K. McIntosh, S. Zvonic, S. Garrett et al., "The immunogenicity of human adipose-derived cells: temporal changes in vitro," Stem Cells, vol. 24, no. 5, pp. 1246-1253, 2006.

[155] B. Puissant, C. Barreau, P. Bourin et al., "Immunomodulatory effect of human adipose tissue-derived adult stem cells: comparison with bone marrow mesenchymal stem cells," British Journal of Haematology, vol. 129, no. 1, pp. 118-129, 2005.

[156] S. S. Tholpady, R. Llull, R. C. Ogle, J. P. Rubin, J. W. Futrell, and A. J. Katz, "Adipose tissue: stem cells and beyond," Clinics in Plastic Surgery, vol. 33, no. 1, pp. 55-62, 2006.

[157] S. Gronthos, D. M. Franklin, H. A. Leddy, P. G. Robey, R. W. Storms, and J. M. Gimble, "Surface protein characterization of human adipose tissue-derived stromal cells," Journal of Cellular Physiology, vol. 189, no. 1, pp. 54-63, 2001.

[158] A. J. B. O. G. Salgado, R. L. G. Reis, N. J. C. Sousa, and J. M. Gimble, "Adipose tissue derived stem cells secretome: soluble factors and their roles in regenerative medicine," Current Stem Cell Research and Therapy, vol. 5, no. 2, pp. 103-110, 2010.

[159] J. Rehman, D. Traktuev, J. Li et al., "Secretion of angiogenic and antiapoptotic factors by human adipose stromal cells," Circulation, vol. 109, no. 10, pp. 1292-1298, 2004.

[160] H. Hauner, K. Rohrig, and T. Petruschke, "Effects of epidermal growth factor (EGF), platelet-derived growth factor (PDGF) and fibroblast growth factor (FGF) on human adipocyte development and function," European Journal of Clinical Investigation, vol. 25, no. 2, pp. 90-96, 1995.

[161] Y. Kubo, S. Kaidzu, I. Nakajima, K. Takenouchi, and F. Nakamura, "Organization of extracellular matrix components during 
differentiation of adipocytes in long-term culture," In Vitro Cellular and Developmental Biology-Animal, vol. 36, no. 1, pp. 38-44, 2000.

[162] Y.-D. C. Halvorsen, D. Franklin, A. L. Bond et al., "Extracellular matrix mineralization and osteoblast gene expression by human adipose tissue-derived stromal cells," Tissue Engineering, vol. 7, no. 6, pp. 729-741, 2001.

[163] Y. Wei, X. Sun, W. Wang, and Y. Hu, "Adipose-derived stem cells and chondrogenesis," Cytotherapy, vol. 9, no. 8, pp. 712716, 2007.

[164] W. S. Khan, S. R. Tew, A. B. Adesida, and T. E. Hardingham, "Human infrapatellar fat pad-derived stem cells express the pericyte marker $3 \mathrm{G} 5$ and show enhanced chondrogenesis after expansion in fibroblast growth factor-2," Arthritis Research \& Therapy, vol. 10, no. 4, article R74, 2008.

[165] B. T. Estes and F. Guilak, "Three-dimensional culture systems to induce chondrogenesis of adipose-derived stem cells," in Adipose-Derived Stem Cells, J. M. Gimble and B. A. Bunnell, Eds., vol. 702 of Methods in Molecular Biology, pp. 201-217, Humana Press, 2011.

[166] J. Wolff, The Law of Bone Remodeling, Translation from the Original: Das Gesetz der Transformation der knochen, August Hirsch, Springer, 1986.

[167] Y.-X. Qin and M. Hu, "Mechanotransduction in musculoskeletal tissue regeneration: effects of fluid flow, loading, and cellularmolecular pathways," BioMed Research International, vol. 2014, Article ID 863421, 12 pages, 2014.

[168] S. Goodman and P. Aspenberg, "Effects of mechanical stimulation on the differentiation of hard tissues," Biomaterials, vol. 14, no. 8, pp. 563-569, 1993.

[169] K. T. Salisbury Palomares, R. E. Gleason, Z. D. Mason et al., "Mechanical stimulation alters tissue differentiation and molecular expression during bone healing," Journal of Orthopaedic Research, vol. 27, no. 9, pp. 1123-1132, 2009.

[170] G. H. Altman, R. L. Horan, I. Martin et al., "Cell differentiation by mechanical stress," The FASEB Journal, vol. 16, no. 2, pp. 270272, 2002.

[171] S. Kapur, D. J. Baylink, and K.-H. W. Lau, "Fluid flow shear stress stimulates human osteoblast proliferation and differentiation through multiple interacting and competing signal transduction pathways," Bone, vol. 32, no. 3, pp. 241-251, 2003.

[172] T. Yoshikawa, S. A. F. Peel, J. R. Gladstone, and J. E. Davies, "Biochemical analysis of the response in rat bone marrow cell cultures to mechanical stimulation," Bio-Medical Materials and Engineering, vol. 7, no. 6, pp. 369-377, 1997.

[173] C. A. Simmons, S. Matlis, A. J. Thornton, S. Chen, C.-Y. Wang, and D. J. Mooney, "Cyclic strain enhances matrix mineralization by adult human mesenchymal stem cells via the extracellular signal-regulated kinase (ERK1/2) signaling pathway," Journal of Biomechanics, vol. 36, no. 8, pp. 1087-1096, 2003.

[174] N. Matsuda, N. Morita, K. Matsuda, and M. Watanabe, "Proliferation and differentiation of human osteoblastic cells associated with differential activation of MAP kinases in response to epidermal growth factor, hypoxia, and mechanical stress in vitro," Biochemical and Biophysical Research Communications, vol. 249, no. 2, pp. 350-354, 1998.

[175] J. M. LaMothe and R. F. Zernicke, "Rest insertion combined with high-frequency loading enhances osteogenesis," Journal of Applied Physiology, vol. 96, no. 5, pp. 1788-1793, 2004.

[176] M. Morinobu, M. Ishijima, S. R. Rittling et al., "Osteopontin expression in osteoblasts and osteocytes during bone formation under mechanical stress in the calvarial suture in vivo," Journal of Bone and Mineral Research, vol. 18, no. 9, pp. 1706-1715, 2003.

[177] R. D. Sumanasinghe, J. A. Osborne, and E. G. Loboa, "Mesenchymal stem cell-seeded collagen matrices for bone repair: effects of cyclic tensile strain, cell density, and media conditions on matrix contraction in vitro," Journal of Biomedical Materials Research A, vol. 88, no. 3, pp. 778-786, 2009.

[178] M. Jagodzinski, M. Drescher, J. Zeichen et al., "Effects of cyclic longitudinal mechanical strain and dexamethasone on osteogenic differentiation of human bone marrow stromal cells," European Cells and Materials, vol. 7, pp. 35-41, 2004.

[179] L. Liu, W. Yuan, and J. Wang, "Mechanisms for osteogenic differentiation of human mesenchymal stem cells induced by fluid shear stress," Biomechanics and Modeling in Mechanobiology, vol. 9, no. 6, pp. 659-670, 2010.

[180] M. Knippenberg, M. N. Helder, B. Z. Doulabi, C. M. Semeins, P. I. J. M. Wuisman, and J. Klein-Nulend, "Adipose tissue-derived mesenchymal stem cells acquire bone cell-like responsiveness to fluid shear stress on osteogenic stimulation," Tissue Engineering, vol. 11, no. 11-12, pp. 1780-1788, 2005.

[181] L. Liu, B. Yu, J. Chen et al., "Different effects of intermittent and continuous fluid shear stresses on osteogenic differentiation of human mesenchymal stem cells," Biomechanics and Modeling in Mechanobiology, vol. 11, no. 3-4, pp. 391-401, 2012.

[182] W. G. Billotte and M.-C. Hofmann, "Establishment of a shear stress protocol to study the mechanosensitivity of human primary osteogenic cells in vitro," Biomedical Sciences Instrumentation, vol. 35, pp. 327-332, 1999.

[183] R. L. Duncan and C. H. Turner, "Mechanotransduction and the functional response of bone to mechanical strain," Calcified Tissue International, vol. 57, no. 5, pp. 344-358, 1995.

[184] M. Hartig, U. Joos, and H.-P. Wiesmann, "Capacitively coupled electric fields accelerate proliferation of osteoblast-like primary cells and increase bone extracellular matrix formation in vitro," European Biophysics Journal, vol. 29, no. 7, pp. 499-506, 2000.

[185] C. H. Lohmann, Z. Schwartz, Y. Liu et al., "Pulsed electromagnetic field stimulation of MG63 osteoblast-like cells affects differentiation and local factor production," Journal of Orthopaedic Research, vol. 18, no. 4, pp. 637-646, 2000.

[186] S. Sun, Y. Liu, S. Lipsky, and M. Cho, "Physical manipulation of calcium oscillations facilitates osteodifferentiation of human mesenchymal stem cells," The FASEB Journal, vol. 21, no. 7, pp. 1472-1480, 2007.

[187] J. B. Haddad, A. G. Obolensky, and P. Shinnick, "The biologic effects and the therapeutic mechanism of action of electric and electromagnetic field stimulation on bone and cartilage: new findings and a review of earlier work," Journal of Alternative and Complementary Medicine, vol. 13, no. 5, pp. 485-490, 2007.

[188] K. E. Hammerick, A. W. James, Z. Huang, F. B. Prinz, and M. T. Longaker, "Pulsed direct current electric fields enhance osteogenesis in adipose-derived stromal cells," Tissue Engineering Part A, vol. 16, no. 3, pp. 917-931, 2010.

[189] S. D. McCullen, J. P. McQuilling, R. M. Grossfeld, J. L. Lubischer, L. I. Clarke, and E. G. Loboa, "Application of low-frequency alternating current electric fields via interdigitated electrodes: effects on cellular viability, cytoplasmic calcium, and osteogenic differentiation of human adipose-derived stem cells," Tissue Engineering-Part C: Methods, vol. 16, no. 6, pp. 1377-1386, 2010.

[190] H. Kotani, H. Kawaguchi, T. Shimoaka et al., "Strong static magnetic field stimulates bone formation to a definite orientation in vitro and in vivo," Journal of Bone and Mineral Research, vol. 17, no. 10, pp. 1814-1821, 2002. 
[191] Y. Yamamoto, Y. Ohsaki, T. Goto, A. Nakasima, and T. Iijima, "Effects of static magnetic fields on bone formation in rat osteoblast cultures," Journal of Dental Research, vol. 82, no. 12, pp. 962-966, 2003.

[192] M. S. Machen, J. E. Tis, N. Inoue, R. H. Meffert, E. Y. S. Chao, and K. A. McHale, "The effect of low intensity pulsed ultrasound on regenerate bone in a less-than-rigid biomechanical environment," Bio-Medical Materials and Engineering, vol. 12, no. 3, pp. 239-247, 2002.

[193] K. Lim, J. Kim, H. Seonwoo, S. H. Park, P.-H. Choung, and J. H. Chung, "In vitro effects of low-intensity pulsed ultrasound stimulation on the osteogenic differentiation of human alveolar bone-derived mesenchymal stem cells for tooth tissue engineering," BioMed Research International, vol. 2013, Article ID 269724, 15 pages, 2013.

[194] Y. Ozawa, N. Shimizu, G. Kariya, and Y. Abiko, "Low-energy laser irradiation stimulates bone nodule formation at early stages of cell culture in rat calvarial cells," Bone, vol. 22, no. 4, pp. 347-354, 1998.

[195] Y. Ueda and N. Shimizu, "Pulse irradiation of low-power laser stimulates bone nodule formation," Journal of Oral Science, vol. 43, no. 1, pp. 55-60, 2001.

[196] M. Mravic, B. Péault, and A. W. James, "Current trends in bone tissue engineering," BioMed Research International, vol. 2014, Article ID 865270, 5 pages, 2014.

[197] P. V. Giannoudis, T. A. Einhorn, and D. Marsh, "Fracture healing: the diamond concept," Injury, vol. 38, supplement 4, pp. S3-S6, 2007.

[198] G. M. Calori and P. V. Giannoudis, "Enhancement of fracture healing with the diamond concept: the role of the biological chamber," Injury, vol. 42, no. 11, pp. 1191-1193, 2011.

[199] P. V. Giannoudis, T. A. Einhorn, G. Schmidmaier, and D. Marsh, "The diamond concept—open questions," Injury, vol. 39, supplement 2, pp. S5-S8, 2008.

[200] E. Yoon, S. Dhar, D. E. Chun, N. A. Gharibjanian, and G. R. D. Evans, "In vivo osteogenic potential of human adiposederived stem cells/poly lactide-co-glycolic acid constructs for bone regeneration in a rat critical-sized calvarial defect model," Tissue Engineering, vol. 13, no. 3, pp. 619-627, 2007.

[201] L. Cui, B. Liu, G. Liu et al., "Repair of cranial bone defects with adipose derived stem cells and coral scaffold in a canine model," Biomaterials, vol. 28, no. 36, pp. 5477-5486, 2007.

[202] P. P. Carvalho, I. B. Leonor, B. J. Smith et al., "Undifferentiated human adipose-derived stromal/stem cells loaded onto wetspun starch-polycaprolactone scaffolds enhance bone regeneration: nude mice calvarial defect in vivo study," Journal of Biomedical Materials Research: Part A, vol. 102, no. 9, pp. 31023111, 2014.

[203] T. Schubert, S. Lafont, G. Beaurin et al., "Critical size bone defect reconstruction by an autologous $3 \mathrm{D}$ osteogenic-like tissue derived from differentiated adipose MSCs," Biomaterials, vol. 34, no. 18, pp. 4428-4438, 2013.

[204] G. Liu, Y. Zhang, B. Liu, J. Sun, W. Li, and L. Cui, "Bone regeneration in a canine cranial model using allogeneic adipose derived stem cells and coral scaffold," Biomaterials, vol. 34, no. 11, pp. 2655-2664, 2013.

[205] C. M. Cowan, Y.-Y. Shi, O. O. Aalami et al., "Adipose-derived adult stromal cells heal critical-size mouse calvarial defects," Nature Biotechnology, vol. 22, no. 5, pp. 560-567, 2004.
[206] C. Di Bella, P. Farlie, and A. J. Penington, "Bone regeneration in a rabbit critical-sized skull defect using autologous adiposederived cells," Tissue Engineering Part: A, vol. 14, no. 4, pp. 483490, 2008.

[207] S. Lendeckel, A. Jödicke, P. Christophis et al., "Autologous stem cells (adipose) and fibrin glue used to treat widespread traumatic calvarial defects: case report," Journal of CranioMaxillofacial Surgery, vol. 32, no. 6, pp. 370-373, 2004.

[208] I. Nomura, K. Watanabe, H. Matsubara, K. Hayashi, N. Sugimoto, and H. Tsuchiya, "Uncultured autogenous adiposederived regenerative cells promote bone formation during distraction osteogenesis in rats," Clinical Orthopaedics and Related Research, vol. 472, no. 12, pp. 3798-3806, 2014.

[209] O. Sunay, G. Can, Z. Cakir et al., "Autologous rabbit adipose tissue-derived mesenchymal stromal cells for the treatment of bone injuries with distraction osteogenesis," Cytotherapy, vol. 15, no. 6, pp. 690-702, 2013.

[210] E. Arrigoni, L. De Girolamo, A. Di Giancamillo et al., "Adiposederived stem cells and rabbit bone regeneration: histomorphometric, immunohistochemical and mechanical characterization," Journal of Orthopaedic Science, vol. 18, no. 2, pp. 331-339, 2013.

[211] S. W. Cheng, Z. Q. Lin, W. Wang et al., "Osteogenic capability of autologous rabbit adipose-derived stromal cells in repairing calvarial defects," Chinese Journal of Traumatology, vol. 14, no. 5, pp. 288-292, 2011.

[212] C.-Y. Lin, Y.-H. Chang, K.-C. Li et al., "The use of ASCs engineered to express BMP2 or TGF- $\beta 3$ within scaffold constructs to promote calvarial bone repair," Biomaterials, vol. 34 , no. 37 , pp. 9401-9412, 2013.

[213] B. Peterson, J. Zhang, R. Iglesias et al., "Healing of critically sized femoral defects, using genetically modified mesenchymal stem cells from human adipose tissue," Tissue Engineering, vol. 11, no. 1-2, pp. 120-129, 2005.

[214] B. Levi, A. W. James, E. R. Nelson et al., "Human adipose derived stromal cells heal critical size mouse calvarial defects," PLoS ONE, vol. 5, no. 6, Article ID e11177, 2010.

[215] H. Kitoh, T. Kitakoji, H. Tsuchiya, M. Katoh, and N. Ishiguro, "Distraction osteogenesis of the lower extremity in patients with achondroplasia/hypochondroplasia treated with transplantation of culture-expanded bone marrow cells and platelet-rich plasma," Journal of Pediatric Orthopaedics, vol. 27, no. 6, pp. 629-634, 2007.

[216] H. W. Doerr, J. Cínatl, M. Stürmer, and H. F. Rabenau, "Prions and orthopedic surgery," Infection, vol. 31, no. 3, pp. 163-171, 2003.

[217] A. Shahdadfar, K. Frønsdal, T. Haug, F. P. Reinholt, and J. E. Brinchmann, "In vitro expansion of human mesenchymal stem cells: choice of serum is a determinant of cell proliferation, differentiation, gene expression, and transcriptome stability," Stem Cells, vol. 23, no. 9, pp. 1357-1366, 2005.

[218] B. Lindroos, S. Boucher, L. Chase et al., "Serum-free, xeno-free culture media maintain the proliferation rate and multipotentiality of adipose stem cells in vitro," Cytotherapy, vol. 11, no. 7, pp. 958-972, 2009.

[219] K. Rajala, B. Lindroos, S. M. Hussein et al., "A defined and xenofree culture method enabling the establishment of clinical-grade human embryonic, induced pluripotent and adipose stem cells," PLoS ONE, vol. 5, no. 4, Article ID e10246, 2010.

[220] W. Im, J.-Y. Chung, S.-H. Kim, and M. Kim, "Efficacy of autologous serum in human adipose-derived stem cells; cell markers, 
growth factors and differentiation," Cellular and Molecular Biology, vol. 57, pp. 1470-1475, 2011.

[221] B. Lindroos, K.-L. Aho, H. Kuokkanen et al., "Differential gene expression in adipose stem cells cultured in allogeneic human serum versus fetal bovine serum," Tissue Engineering. Part A, vol. 16, no. 7, pp. 2281-2294, 2010.

[222] L. Kucerova, V. Altanerova, M. Matuskova, S. Tyciakova, and C. Altaner, "Adipose tissue-derived human mesenchymal stem cells mediated prodrug cancer gene therapy," Cancer Research, vol. 67, no. 13, pp. 6304-6313, 2007.

[223] F. L. Muehlberg, Y.-H. Song, A. Krohn et al., "Tissue-resident stem cells promote breast cancer growth and metastasis," Carcinogenesis, vol. 30, no. 4, pp. 589-597, 2009.

[224] B. Cousin, E. Ravet, S. Poglio et al., "Adult stromal cells derived from human adipose tissue provoke pancreatic cancer cell death both in vitro and in vivo," PLoS ONE, vol. 4, no. 7, Article ID e6278, 2009.

[225] J. M. Yu, E. S. Jun, Y. C. Bae, and J. S. Jung, "Mesenchymal stem cells derived from human adipose tissues favor tumor cell growth in vivo," Stem Cells and Development, vol. 17, no. 3, pp. 463-473, 2008.

[226] G. Grisendi, R. Bussolari, L. Cafarelli et al., "Adipose-derived mesenchymal stem cells as stable source of tumor necrosis factor-related apoptosis-inducing ligand delivery for cancer therapy," Cancer Research, vol. 70, no. 9, pp. 3718-3729, 2010.

[227] L. T. Donnan, M. Saleh, A. S. Rigby, and A. McAndrew, "Radiographic assessment of bone formation in tibia during distraction osteogenesis," Journal of Pediatric Orthopaedics, vol. 22, no. 5, pp. 645-651, 2002.

[228] M. R. Hamdy and J. McCarthy, "Monitoring of regenerate bone," in Management of Limb-Length Discrepancies, pp. 191196, American Academy of Orthopaedic Surgeons, Rosemont, Ill, USA, 2011.

[229] A. M. Makhdom, L. Nayef, M. Tabrizian, and R. C. Hamdy, "The potential roles of nanobiomaterials in distraction osteogenesis," Nanomedicine: Nanotechnology, Biology, and Medicine, vol. 11, no. 1, pp. 1-18, 2015. 


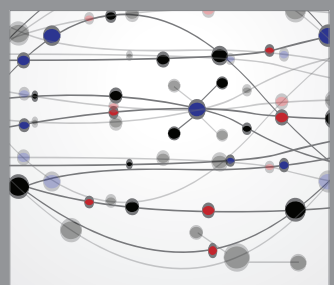

The Scientific World Journal
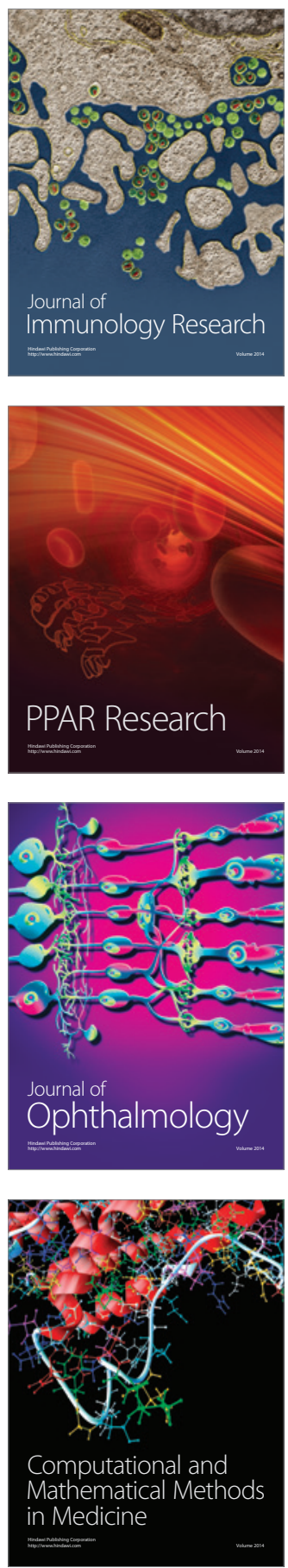

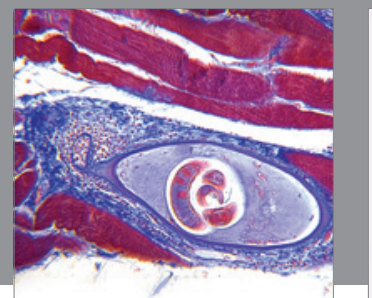

Gastroenterology

Research and Practice
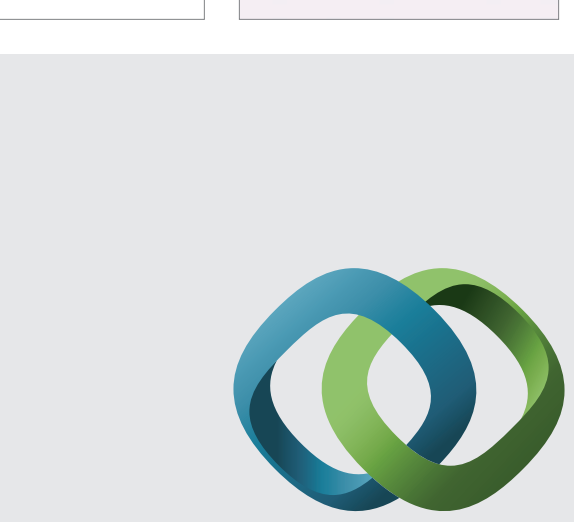

\section{Hindawi}

Submit your manuscripts at

http://www.hindawi.com
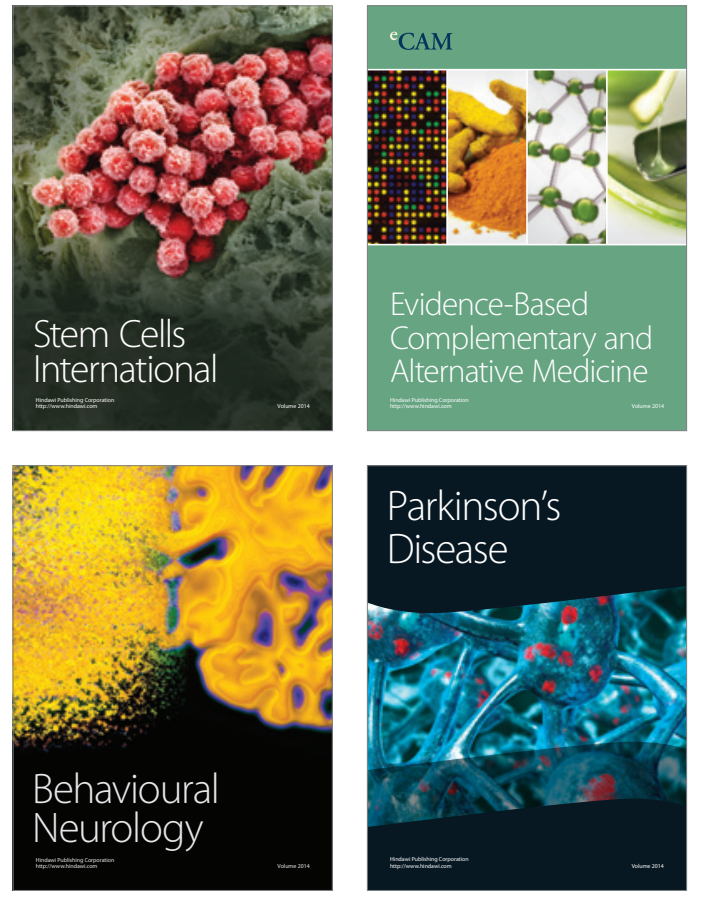
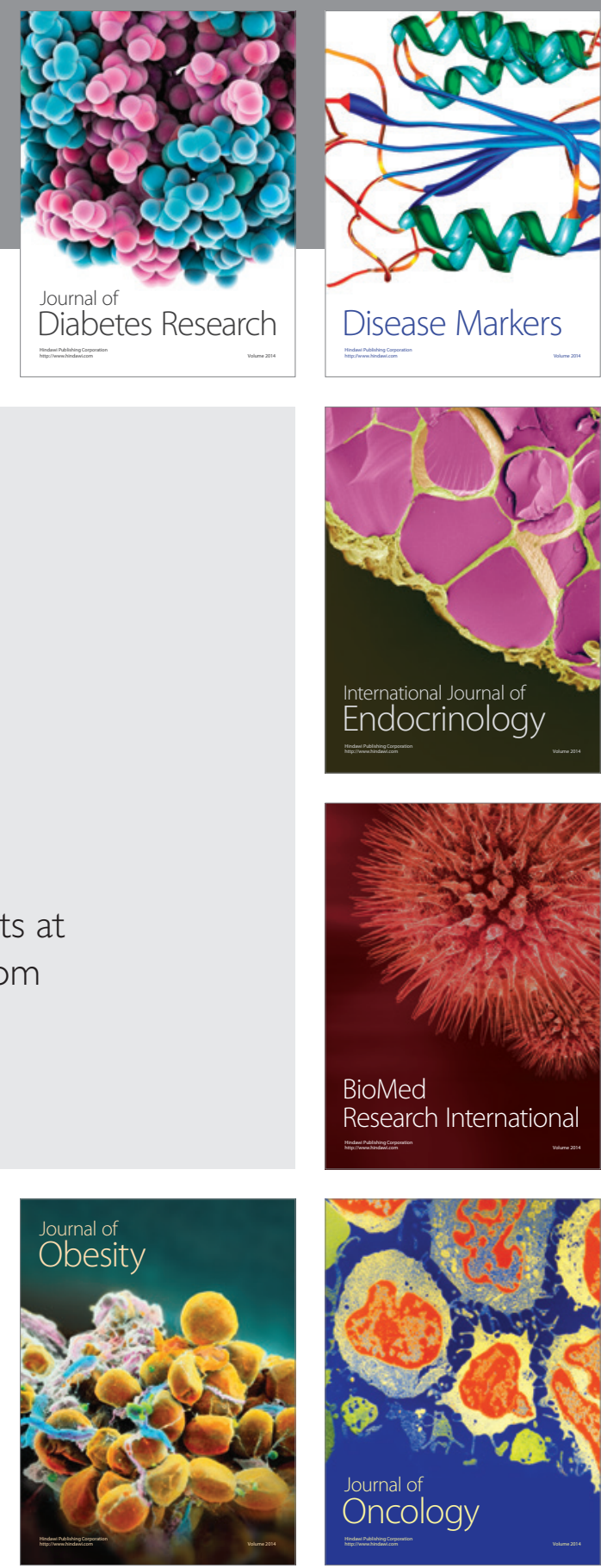

Disease Markers
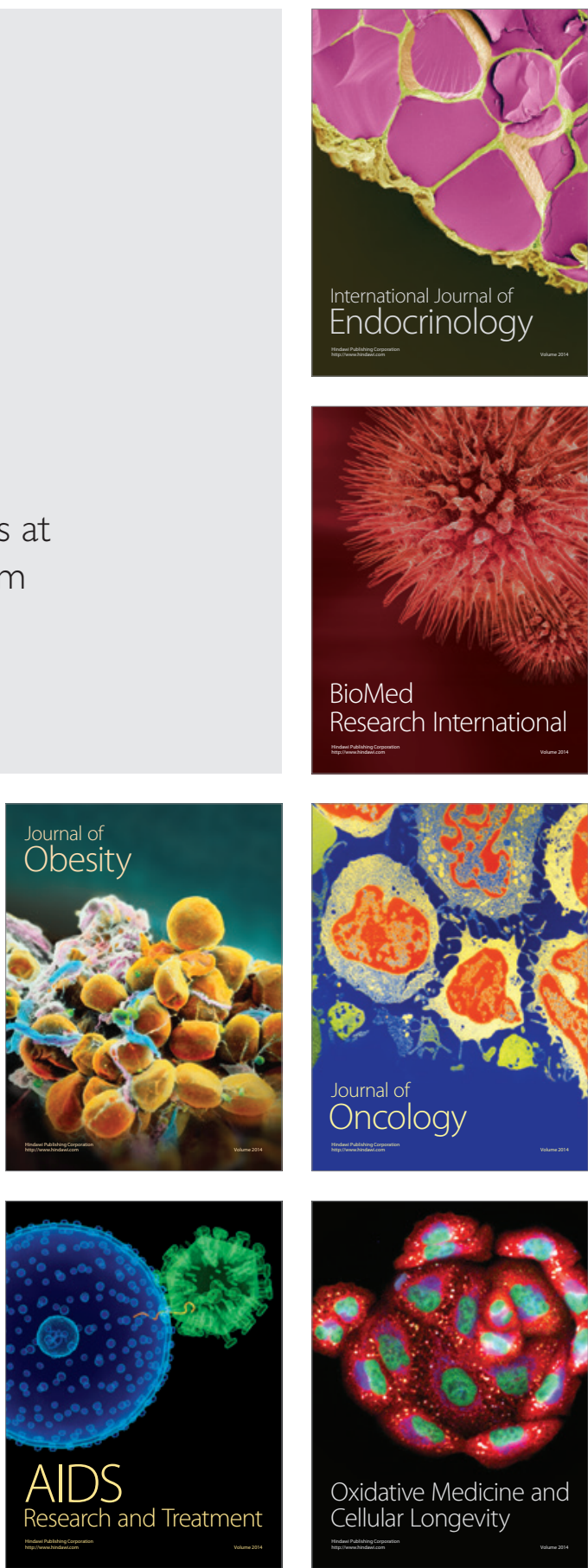